\title{
Some Slope-Movement Problems in Windsor County, Vermont, 1984
}

\section{U.S. GEOLOGICAL SURVEY BULLETIN 1828}

Prepared in cooperation with the Vermont Geological Survey

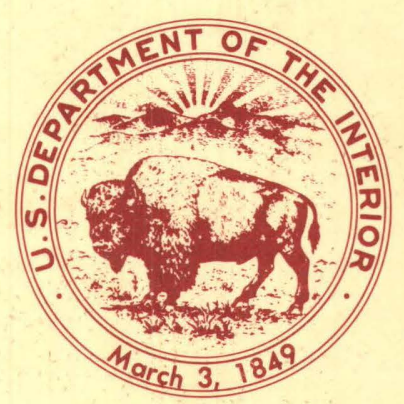


Instructions on ordering publications of the U.S. Geological Survey, along with prices of the last offerings, are given in the current-year issues of the monthly catalog "New Publications of the U.S. Geological Survey." Prices of available U.S. Geological Survey publications released prior to the current year are listed in the most recent annual "Price and Availability List." Publications that are listed in various U.S. Geological Survey catalogs (see back inside cover) but not listed in the most recent annual "Price and Availability List" are no longer available.

Prices of reports released to the open files are given in the listing "U.S. Geological Survey Open-File Reports," updated monthly, which is for sale in microfiche from the U.S. Geological Survey, Books and Open-File Reports Section, Federal Center, Box 25425, Denver, CO 80225. Reports released through the NTIS may be obtained by writing to the National Technical Information Service, U.S. Department of Commerce, Springfield, VA 22161; please include NTIS report number with inquiry.

Order U.S. Geological Survey publications by mail or over the counter from the offices given below.

\section{BY MAIL}

\section{Books}

Professional Papers, Bulletins, Water-Supply Papers, Techniques of Water-Resources Investigations, Circulars, publications of general interest (such as leaflets, pamphlets, booklets), single copies of Earthquakes \& Volcanoes, Preliminary Determination of Epicenters, and some miscellaneous reports, including some of the foregoing series that have gone out of print at the Superintendent of Documents, are obtainable by mail from

\section{U.S. Geological Survey, Books and Open-File Reports Federal Center, Box 25425 Denver, CO 80225}

Subscriptions to periodicals (Earthquakes \& Volcanoes and Preliminary Determination of Epicenters) can be obtained ONLY from the

\section{Superintendent of Documents \\ Government Printing Office \\ Washington, D.C. 20402} ments.)

(Check or money order must be payable to Superintendent of Docu-

\section{Maps}

For maps, address mail orders to

\section{U.S. Geological Survey, Map Distribution \\ Federal Center, Box 25286 \\ Denver, CO 80225}

Residents of Alaska may order maps from

\author{
Alaska Distribution Section, U.S. Geological Survey, \\ New Federal Building - Box 12 \\ 101 Twelfth Ave., Fairbanks, AK 99701
}

\section{OVER THE COUNTER}

\section{Books}

Books of the U.S. Geological Survey are available over the counter at the following Geological Survey Public Inquiries Offices, all of which are authorized agents of the Superintendent of Documents:

- WASHINGTON, D.C.--Main Interior Bldg., 2600 corridor, 18 th and C Sts., NW.

- DENVER, Colorado--Federal Bldg., Rm. 169, 1961 Stout St.

- LOS ANGELES, California--Federal Eldg., Rm. 7638, 300 N. Los Angeles St.

- MENLO PARK, California--Bldg. 3 (Stop 533), Rm. 3128, 345 Middlefield Rd.

- RESTON, Virginia--503 National Center, Rm. 1C402, 12201 Sunrise Valley Dr.

- SALT LAKE CITY, Utah--Federal Bldg., Rm. 8105, 125 South State St.

- SAN FRANCISCO, California--Customhouse, Rm. 504, 555 Battery St.

- SPOKANE, Washington--U.S. Courthouse, Rm. 678, West 920 Riverside Ave..

- ANCHORAGE, Alaska--Rm. 101, 4230 University Dr.

- ANCHORAGE, Alaska--Federal Bldg, Rm. E-146, 701 C St.

\section{Maps}

Maps may be purchased over the counter at the U.S. Geological Survey offices where books are sold (all addresses in above list) and at the following Geological Survey offices:

- ROLLA, Missouri--1400 Independence Rd.

- DENVER, Colorado--Map Distribution, Bldg. 810, Federal Center

- FAIRBANKS, Alaska--New Federal Bldg., 101 Twelfth Ave. 


\section{Some Slope-Movement Problems in Windsor County, Vermont, 1984}

\section{BY CHARLES A. BASKERVILLE and GREGORY C. OHLMACHER}

Prepared in cooperation with the Vermont Geological Survey

A study of the variety of slope movements that developed in Windsor County, Vermont, involving a representative group of

Pleistocene surficial materials 


\section{DEPARTMENT OF THE INTERIOR DONALD PAUL HODEL, Secretary \\ U.S. GEOLOGICAL SURVEY \\ Dallas L. Peck, Director}

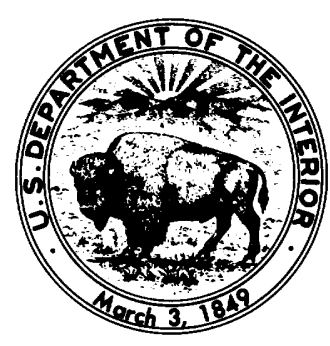

UNITED STATES GOVERNMENT PRINTING OFFICE: 1988

For sale by the Books and Open-File Reports Section, U.S. Geological Survey Federal Center, Box 25425, Denver, CO 80225

\section{Library of Congress Cataloging in Publication Data}

Baskerville, Charles A.

Some slope movement problems in Windsor County, Vermont, 1984.

(U.S. Geological Survey bulletin ; 1828)

Bibliography: $p$.

Supt. of Docs. no.: I 19.3:1828

1. Landslide-Vermont-Windsor County. I. Ohlmacher, Gregory C.

II. Vermont Geological Survey. III. Title. IV. Series.

$\begin{array}{llrr}\text { QE75.B9 } & \text { no. } 1828 & 557.3 \mathrm{~s} & 87-600417\end{array}$

[QE599.U5]

[551.3] 


\title{
CONTENTS
}

\author{
Abstract 1 \\ Introduction 1 \\ Acknowledgments 1 \\ Physiography 3 \\ Geologic setting 3 \\ Weather conditions 3 \\ Slope failures in Vermont 4 \\ The problem 4 \\ Rising ground water as a triggering mechanism for slope movements 5 \\ Slope-movement classification $\quad 6$ \\ Susceptibility of glacial lake-bottom deposits to sliding $\quad 6$ \\ North Hartland Flood-Control Reservoir $\quad 10$ \\ Earth flows $\quad 10$ \\ Piping associated with earth flows $\quad 12$ \\ Vermont Route $11 \quad \mathbf{1 3}$ \\ U.S. Route $5 \quad 14$ \\ North Springfield Flood-Control Reservior $\quad 15$ \\ Sharon slope failure $\mathbf{1 6}$ \\ Slope movements in ice-marginal deposits $\quad \mathbf{2 0}$ \\ Slope movements in till deposits $\mathbf{2 1}$ \\ Brook Road 21 \\ Holbrook Hill Road 23 \\ Summary and conclusions $\quad 24$ \\ References cited $\quad 25$
}

\section{FIGURES}

1. Windsor County, Vt., locality map 2

2. Bar graph showing mean monthly rainfall-snowfall for the period September 1, 1983, to June 30, 1984, for all New England stations 3

3. Classification of slope movements 7

4. Photograph of the Glacial Lake Hitchcock rhythmite deposit at the North Springfield Flood-Control Reservoir 7

5. Schematic cross section of a typical flood-reservoir slope configuration 9

6. Map locating the North Hartland Flood-Control Reservoir slide area 10

7. Photograph of slope movement on the northeastern wall of the North Hartland Flood-Control Reservoir 11

8. Photograph of slickensides on a clay-smeared head-scarp surface of the slumpearth flow on the northeastern valley wall of the North Hartland Flood-Control Reservoir 11

9. Block diagram showing rafts of intact material sliding on fluidized substrate $\mathbf{1 2}$

10. Photograph of part of the southwestern valley wall of the North Hartland FloodControl Reservoir showing piping cavities 
11. Map locating the Vermont Route 11 slide

12. Schematic cross section of the terrace configuration at the Vermont Route 11 landslide site $\quad 13$

13. Map locating the Route 5 and Brook Road slides $\quad \mathbf{1 4}$

14. Map locating the North Springfield Flood-Control Reservoir slide area 15

15. Block diagram section sketches depicting the processes for the formation of multiple ridges or hummocks at the eastern abutment at the North Springfield Dam 17

16. Map locating the Sharon slide area $\mathbf{1 8}$

17. Views of the landslide site north of Sharon on Vermont Route $14 \quad \mathbf{1 8}$

18. Enlarged portion of aerial photograph of the Stoughton Pond area $\mathbf{2 0}$

19. A block-section sketch of a portion of the eastern shore of Stoughton Pond that shows the reservoir-terrace kettle-rim relation

21

20. Photograph of piping failures at Stoughton Pond 23

21. Map locating the Holbrook Hill Road slide area $\mathbf{2 3}$

\section{TABLES}

1. Precipitation and ground-water data for Windsor County, Vt. 4

2. Torvane and penetrometer tests taken in four glacial lake-bottom deposit sites in Windsor County, Sharon excluded 8

3. Torvane and penetrometer tests of the varved deposits on the Sharon, Vt., slope 19

4. Soil stratigraphy of three adjacent areas on the eastern shore of Stoughton Pond 22 


\title{
Some Slope-Movement Problems in Windsor County, Vermont, 1984
}

\author{
By Charles A. Baskerville and Gregory C. OhImacher
}

\begin{abstract}
During 1984 in Windsor County, Vermont, an abnormal number of slope movements, including flows, slumps, and block slides in tills and glacial lake deposits, blocked main highways, closed secondary roads, and caused substantial damage to flood-control reservoirs. In one case, a home and its surrounding land were swept away, as the result of stream-bank failure due to heavy flooding. These slope movements were triggered by heavy rainfall and the melting of a thick snowpack. A statewide monthly average rainfall of 3.39 inches (8.61 centimeters) from February through the end of April and an 8.96-inch (22.76-centimeter) average for May 1984 contributed to numerous floods and slope movements in the State. From February through May, the average monthly rainfall for the southeastern part of Vermont, which includes Windsor County, was 6.48 inches (16.47 centimeters).

Mapping and sampling of the 1984 landslides in glacial till and lake-bed deposits in Windsor County were carried out to determine the processes involved in these slope movements. Although specific landslide processes varied from site to site, the landslides can be subdivided into groups based on the surficial materials present. The most common slope movement was found to be the earth flow, which occurred in rhythmite deposits. In clayey till deposits, a mixture of blockslide, slump, and earth-flow slope movements was found. Failures involving bedrock also can be found in Windsor County, but none were directly attributable to the $1983-84$ storms.
\end{abstract}

\section{INTRODUCTION}

Field studies were made of landslides that occurred during spring 1984 in Windsor County, Vt. Some of these slides were selected for presentation here as representative of the slope-movement problems found within the county. The area in which the slides occurred is bounded approximately by the White River valley on the north, the Connecticut River valley on the east, the Green Mountains on the west, and the Williams River valley on the south (see fig. 1).
The landslide sites chosen for study represent a variety of slope movements involving various types of surficial deposits found in Windsor County. The most extensive surficial deposits include Pleistocene till, glaciofluvial, and glaciolacustrine sediments (Stewart and Mac Clintock, 1969). Regardless of a slope's composition, the above-normal precipitation affected slope stability in all the soil types studied in the county.

As used in this report, the term "slope movement" refers to various types of slides and flows in unconsolidated materials. Although rock falls and topples occurred in the county, they are not dealt with in this report. Slope movements studied in most of the valleys included slides, flows, and complex forms. These variations occurred in relatively small geographic areas and were primarily the result of differences in materials. Slope movements in the vicinity of the North Hartland and the North Springfield Flood-Control Reservoirs on the Ottauquechee and the Black Rivers,respectively, are of particular interest (fig. 1) because several types of landslide mechanisms occur at these sites.

New and reactivated landslides were studied. Some of the reactivated slides and flows examined were drilled by soil auger to determine any near-surface variation in the materials as well as to sample the materials present.

\section{Acknowledgments}

This landslide research project is a cooperative effort between the Vermont Geological Survey of the Agency of Natural Resources and the U.S. Geological Survey. Discussions with Charles A. Ratté, Vermont State Geologist; Frank J. Lanza, Chief Geologist; and Dan Cadiz of the State of Vermont Agency of Transportation have been very informative. We also wish to thank Michael Curran, upper Connecticut River Basin Manager, and Thomas Coen and James E. Dyer, Project Managers, North Springfield and North Hartland Dams, respectively, New England Division, U.S. Army Corps of Engineers, for their assistance, discussions of reservoir landslide problems, and general cooperation on this project. Our 


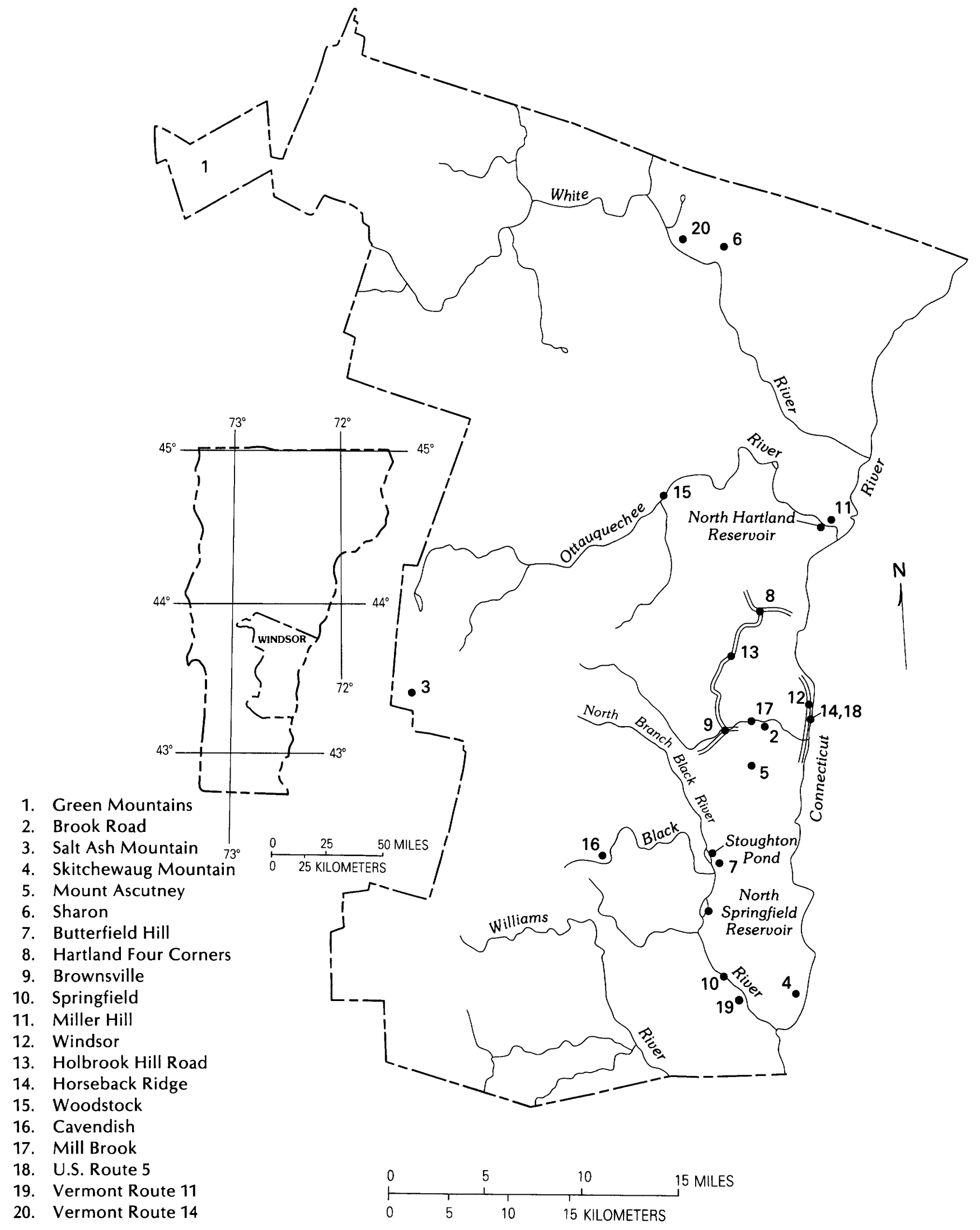

Figure 1. Windsor County, Vt., locality map. Numbers indicate places mentioned in the text. 
gratitude goes out to our colleague, Carl Koteff, U.S. Geological Survey, who took the time to accompany us on visits to some of our sites. Discussions with Carl on the glacial history of the area were very enlightening. Special thanks also are due Dr. Ratté and William E. Davies, U.S. Geological Survey, for their critical reading and helpful suggestions on the original manuscript. We also appreciate the review and helpful suggestions given the final manuscript by David K. Keefer, U.S. Geological Survey.

\section{Physiography}

Windsor County is located in eastern Vermont to the east of the Green Mountains. The county is drained by the White, Ottauquechee, Black, and Williams Rivers and their tributaries and by Mill Brook. These streams flow eastward into the Connecticut River. The area is quite hilly, and the topography is controlled mostly by generally north-south-striking bedrock structures. Ridge-crest elevations range from as high as 3,286 ft $(1,002 \mathrm{~m})$ at Salt Ash Mountain (fig. 1, locality 3) near the northwestern corner of the county to slightly over $900 \mathrm{ft}(274 \mathrm{~m})$ at Skitchewaug Mountain (fig. 1, locality 4) along the Connecticut River near the southeastern corner of the county. Mount Ascutney (fig. 1, locality 5), a monadnock on the eastern side of Windsor County adjacent to the Connecticut River, is 3,144 ft $(958 \mathrm{~m})$ in elevation. Valley bottom elevations average from 1,100 to $1,300 \mathrm{ft}(335-396$ $\mathrm{m}$ ) in the western part of Windsor County and from 300 to $500 \mathrm{ft}(91.4-152 \mathrm{~m})$ in the eastern part.

The entire region has been glaciated, which gives much of the topographic surface a rolling aspect in many broad valley areas. The authors' observations show that the glacial deposits are thick in valleys and relatively thin on upper parts of ridges and mountain sides.

\section{Geologic Setting}

In the southern one-half of Windsor County, the bedrock includes the Precambrian Mount Holly Complex, which is composed of gneisses, quartzites, and marbles. The Silurian Waits River and the Silurian(?)-Devonian Gile Mountain Formations, which are stratigraphically above the Mount Holly Complex (Hepburn and others, 1984), are found mostly in the northern one-half of the county. The Waits River Formation is composed of three major interbedded rock types-impure marbles, quartzites, and schists. The Gile Mountain Formation consists of micaceous and feldspathic quartzites and mica schists, a marble member, and fine-grained phyllites. Mount Ascutney is composed of Late Jurassic or Early Cretaceous granites, syenites, and volcanics (Faul and other, 1963).

The surficial materials are mostly late Wisconsinan glacial drift (Stewart and Mac Clintock, 1969) and include till, glaciofluvial, and glaciolacustrine deposits. The glaciolacustrine deposits are associated with Glacial Lake Hitchcock, which covered much of the Connecticut River valley and its tributaries during the retreat of the late Wisconsinan ice sheet. Many of the river valleys contain till overlain by rhythmically bedded silt and clay lakebottom deposits (rhythmites). In some places, the lakebottom deposits are overlain by late glacial deltas composed of fine sand, cobbles, and gravel and (or) by colluvium. Glaciofluvial deposits consisting of sand to coarse gravel are common in the upland valleys.

\section{Weather Conditions}

Slope stability is related closely to the amount of precipitation that falls in a given time interval (Zaruba and Mencl, 1982). The rate of rainfall coupled with soil or sediment properties of water absorption, infiltration, and retention are the critical hydrogeological factors associated with slope failure. The weather conditions prevailing in New England in general and in Windsor County in particular for the period of September 1, 1983, through June 30, 1984 (National Oceanic and Atmospheric Administration, 1983a-d, 1984a-f), are summarized in figure 2 .

The weather records for February 1984 show that the region, including Windsor County, had above-normal rainfall and that snow fell over most of the region from 3

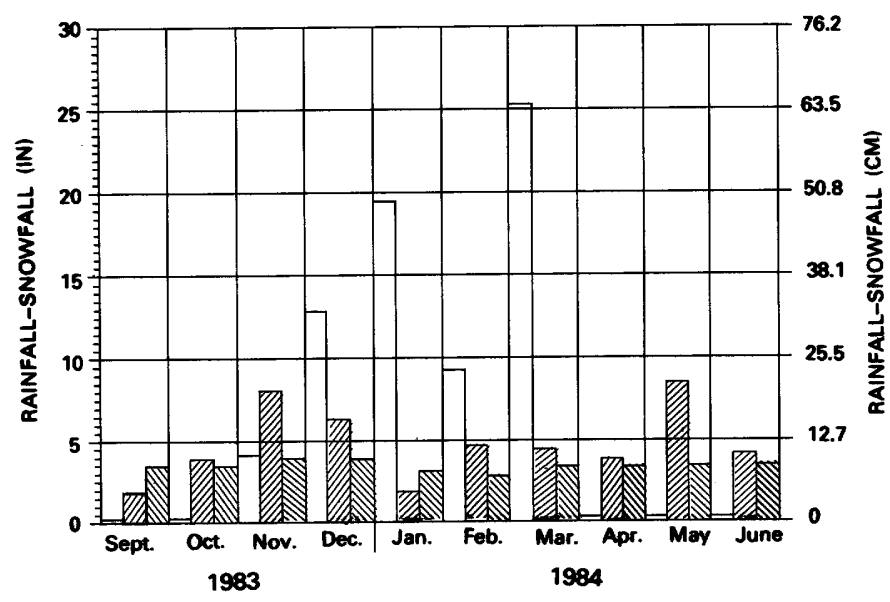

Figure 2. Mean monthly rainfall-snowfall for the period from September 1, 1983, to June 30, 1984, for all New England stations. Approximate snowpack equivalent to water is 3.95 in. $(10 \mathrm{~cm})$ of snow to $0.395 \mathrm{in}$. $(1 \mathrm{~cm})$ of rain. From left to right at each month, the first (open) bar shows total unmelted snow and sleet for the month in New England. The second bar (hachures sloping down to the left) show the average of total liquid and melted frozen precipitation combined for New England. The third bar (hachures sloping down to the right) shows the normal precipitation in the form of rain for the month. Data from the National Oceanic and Atmospheric Administration (1983a-d, 1984a-f). 
to 15 days of the month (National Oceanic and Atmospheric Administration, 1984b).

During winter and early spring 1984, the total snowfall recorded was $95.5 \mathrm{in} .(242.6 \mathrm{~cm})$ at Woodstock, in the northern one-half of Windsor County, and was 85.7 in. $(217.7 \mathrm{~cm})$ at Cavendish, in the southern one-half of the county; this snow cover is roughly equal to 9.6 and 8.6 in. (24.4 and $21.8 \mathrm{~cm}$ ), respectively, of rainfall.

Abnormal precipitation raised ground-water well levels (table 1), which increased the moisture content to near saturation of the soil materials in Windsor County during fall 1983 through midspring 1984. Unusually intense spring storms in late May exacerbated the conditions by increasing the pore-water pressure in the sediments, thus triggering slides.

Although table 1 shows some fluctuation in the ground-water levels, in general, they were above average for the period of interest. On the basis of these well records, it is assumed that the ground-water levels were higher than normal throughout the county.

\section{SLOPE FAILURES IN VERMONT}

The entire Green Mountain and Taconic Mountain ranges and their contained river valleys have been found to have slope failures in just about every geologic material and unit encountered. In rock terrane, large rock falls have been observed in gneisses, schists, and quartzites; rock slumps, in quartzites; topples, in marbles; and debris slides, in schists. In unconsolidated sediments, earth flows and slumps, debris flows, and debris slides are common types of slope movements. In some instances where massive bare rock outcroppings dominate long ridges, rock falls and rock slides have triggered earth and (or) debris slides or flows, thus creating complex types of movement. Several hundred landslides have been located in the field - some were just noted on maps; others have been studied in detail, measured, sampled, and tested; and many more have been located and mapped by use of remotely sensed data.

\section{THE PROBLEM}

All the landslides discussed in this report occurred during and immediately following the heavy rains and rapid snowmelt that inundated the New England region during spring 1984. The culmination was exceptionally heavy rain that fell during the last few days of May. In Vermont, the damage that resulted from some slope failures involved flood-control reservoir slopes, road

Table 1. Precipitation and ground-water data for Windsor County, Vt.

[Precipitation data taken from U.S. Army Corps of Engineers records kept at the North Hartland and North Springfield Flood-Control Reservoir sites. Ground-water well readings supplied by David Butterfield of the Vermont Department of Water Resources. Chester, Hartland, and Rochester wells are in unconfined aquifers, and Queechee-West Hartford is confined partially in bedrock; recharge area is about $100 \mathrm{to} 200 \mathrm{ft}$ (30-60 m) from this well. All these wells are local quick-response types and cover no more than 1,000-acre drainage basins; all are within Windsor County (James Ashley, Vermont Department of Water Resources, personal commun. 1986)]

\begin{tabular}{|c|c|c|c|c|c|c|}
\hline \multirow[b]{2}{*}{ Date } & \multicolumn{2}{|c|}{ Total precipitation ${ }^{1}$} & \multicolumn{4}{|c|}{ Ground-water well readings } \\
\hline & North Hartland & North Springfield & $\begin{array}{c}\text { Chester } \\
\text { well }\end{array}$ & $\begin{array}{c}\text { Hartland } \\
\text { well }\end{array}$ & $\begin{array}{l}\text { Rochester } \\
\text { well }\end{array}$ & $\begin{array}{l}\text { Quechee-West } \\
\text { Hartford well }\end{array}$ \\
\hline \multicolumn{7}{|l|}{ 1983: } \\
\hline \multirow[t]{3}{*}{ September } & 1.97 & 2.28 & 36.09 & 39.60 & ${ }^{3} 12.37$ & ${ }^{3} 5.32$ \\
\hline & $(5.00)$ & $(5.79)$ & $3(1.86)$ & ${ }^{3}(2.93)$ & ${ }^{3}(3.77)$ & ${ }^{3}(1.62)$ \\
\hline & & & ${ }^{4}(-0.10)$ & ${ }^{4}(0.06)$ & ${ }^{4}(-0.07)$ & - \\
\hline \multirow[t]{4}{*}{ October.. } & 2.66 & 2.95 & 5.83 & 9.63 & 12.36 & 6.38 \\
\hline & $(6.76)$ & $(7.49)$ & $(1.78)$ & $(2.94)$ & $(3.77)$ & $(1.94)$ \\
\hline & & & -0.48 & -0.26 & -0.95 & - \\
\hline & & & $(-0.15)$ & $(-0.08)$ & $(-0.29)$ & - \\
\hline November... & & & $(+0.07)$ & $(-0.04)$ & $(+0.25)$ & - \\
\hline \multirow[t]{4}{*}{ December. } & 5.89 & 6.65 & ${ }^{5} 3.40$ & 7.47 & 6.50 & $6+1.35$ \\
\hline & $(14.96)$ & $(16.98)$ & ${ }^{5}(1.04)$ & $(2.28)$ & $(1.98)$ & $6(+0.41)$ \\
\hline & & & +1.60 & +1.31 & +4.08 & - \\
\hline & & & $(+0.49)$ & $(+0.40)$ & $(+1.24)$ & - \\
\hline
\end{tabular}


Table 1. Precipitation and ground-water data for Windsor County, Vt.-Continued

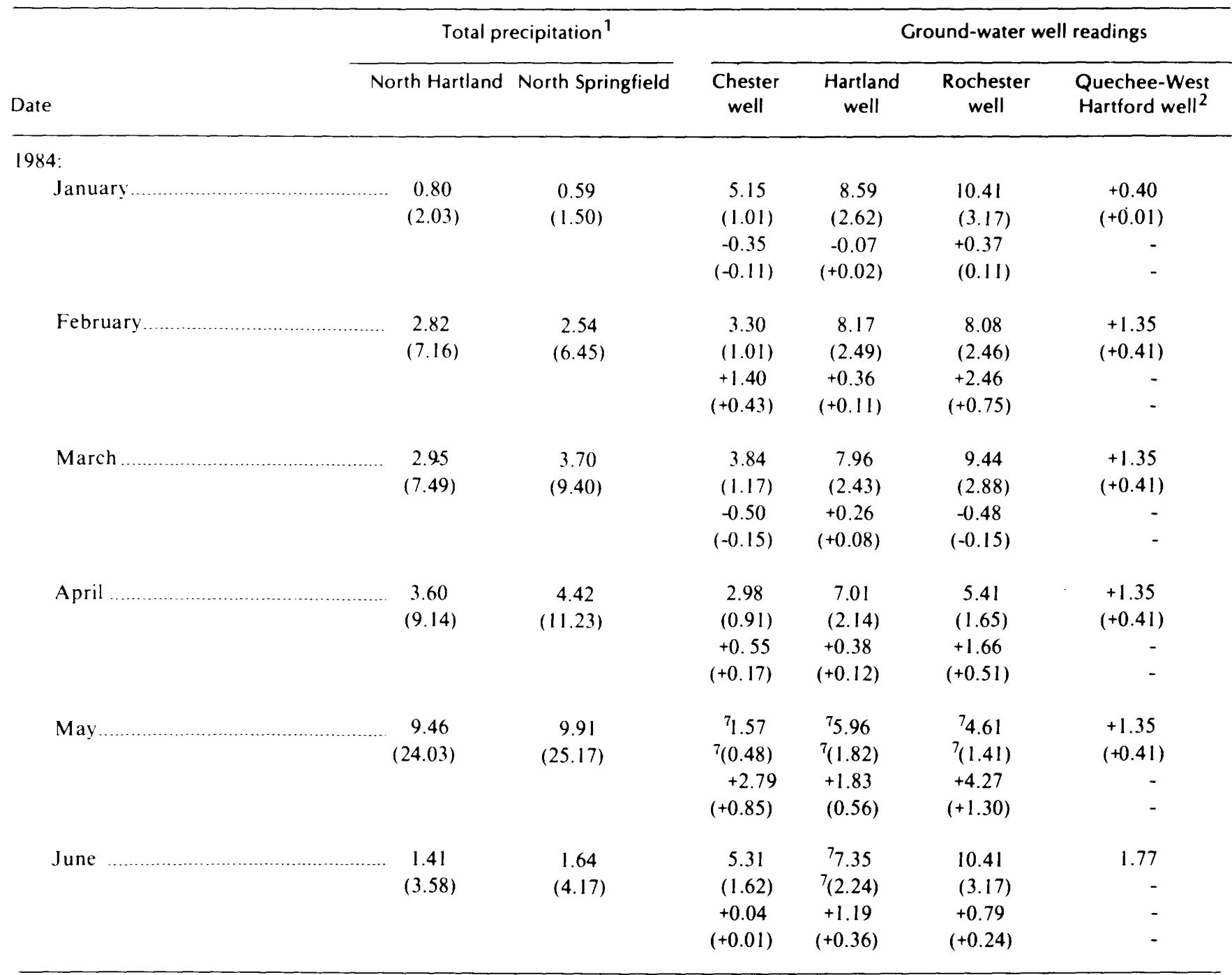

\footnotetext{
I Includes melted snow and ice in inches and centimeters ().

${ }^{2}$ Flowing well. + readings indicate level above ground surface.

${ }^{3}$ Water level below ground surface in feet and meters ().

${ }^{4}$ Departure from average for that month in feet \pm and meters () \pm .

${ }^{5}$ New high record for December.

$6+1.35-\mathrm{ft}(0.41-\mathrm{m})$ readings are for flow from casing slot cut above ground level at that elevation.

${ }^{7}$ New high record.
}

NOTES: To save repetition, the values for the four water wells for every month follow the pattern for the values shown for September after footnotes 3 and 4 .

Average for the month can be determined by adding or subtracting the + or - amount indicated by the values before footnote 4 from the water level numbers before footnote 3 for any month.

traffic disruptions, felled trees, and telephone lines. Fortunately, no lives were lost, and no one was injured. Because of the great number of slides that occurred, Windsor County was selected as a primary area of study. During a reconnaissance of the county in the first week of July 1984, it was observed that more than one type of landslide had occurred in the various glacial deposits. The slope movements selected for detailed study were mainly earth flows and block slides.

\section{RISING GROUND WATER AS A TRIGGERING MECHANISM FOR SLOPE MOVEMENTS}

In every case of slope movement studied in the Windsor County lake bed and till deposits in 1984, abovenormal amounts of water played a major role in initiating and sustaining failure. Above-normal precipitation led to elevated ground-water levels, which, in turn, led to 
increased pore-water pressure. Related to the increased pore-water pressure was a decrease in effective normal stress and a corresponding decrease in shearing resistance in the soil (Terzaghi and Peck, 1948; Skempton and DeLory, 1957; Campbell, 1975). Failure occurs when the shearing resistance decreases below a critical level; this level is dependent on the type of material involved in the failure and the slope geometry.

High water levels behind the North Springfield and the North Hartland Flood-Control Dams helped to raise ground-water levels and to increase pore-water pressures. Schuster (1980) stated that high water levels behind dams can lead to elevated pore-water pressures and can cause slope failures in the reservoirs. It was noted that all the slope movements that occurred in the flood-control reservoirs in Windsor County had head scarps at or below the high-water level for spring 1984. This fact may be related to rapid drawdown (Terzaghi, 1950, fig. 7). The pore spaces on the reservoir rim are filled to the head-scarp level. Following rapid reservoir drawdown, a time lag occurs between decreases in the reservoir level and in the water-table surface. In the toe area, this generates high seepage pressures, which produce slope instability and sliding (Terzaghi, 1950).

Manmade slope alterations also played a major role in raising ground-water levels. Surface runoff tended to concentrate at the low points along the benches, which were old or abandoned unimproved roads and trails along some hillsides. With time, the soil slopes below these low points became saturated, and slope failures developed, sometimes beginning as creep. The failure along U.S. Route 5 at Windsor (fig. 1, locality 18) and those that occurred along Holbrook Hill Road (fig. 1, locality 13) near Hartland Four Corners (fig. 1, locality 8) are examples of slope movements that occurred below old roads and trails.

\section{SLOPE-MOVEMENT CLASSIFICATION}

This paper uses the slope-movement classification developed by Varnes (1978) (fig. 3), which has become widely accepted by landslide researchers. Slope movements are classified according to the type of material involved and the type of movement.

All the materials involved in the slope movements discussed in this study are considered to be engineering soils. Such soils are unconsolidated, residual, or transported inorganic mineral matter and (or) rock fragments. The soils ranged from very fine grained silts and clays to coarser grained materials composed of sand, gravel, cobbles, and boulders. In this report, the finer grained soils are referred to as earth, and the coarser mixtures are considered to be debris (Varnes, 1978).

Within the study area, slope movements were diverse and identified as mostly rotational or translational slides, flows, and complex types. Some of the slope movements studied in flood-control reservoirs included piping in sand and gravel strata. This indicates a high-velocity water flow as the water table, raised during flooding, attempted to reestablish itself at its normally lower level after reservoir drawdown.

Slope movements that occurred during late spring and early summer 1984 in Windsor County were divided into groups based on the nature of the glacial deposits. The first, and by far the most common, group of landslides occurred in deposits composed of varved silts and clays, or rhythmites. The second group of slope failures occurred in glacial till deposits. A few slope movements occurred along the sides of ice-marginal deposits; for example, kames. One slope movement of special interest, located in Sharon, Vt. (fig. 1, locality 6), is a complex deposit composed of stream-terrace sediments, above which overlie glaciolacustrine sediments, which, in turn, overlie esker deposits.

\section{SUSCEPTIBILITY OF GLACIAL LAKE-BOTTOM DEPOSITS TO SLIDING}

Rhythmites, which represent the greatest landslide problems found in the study area, generally are composed of alternating layers of silty-clay and silt to fine sand. Generally, the rhythmite deposits in the county range from nearly pure clays to silts and sand. Where layers of nearly pure clay are found, they are very thin, usually less than 1 in. $(2.54 \mathrm{~cm})$. The average thickness of glacial lake-bottom deposits, as measured on lateral scarps and head scarps, at the sites investigated is $50 \mathrm{ft}(15.24 \mathrm{~m})$. Contained within a few rhythmite sequences are layers of medium to coarse sand and gravel. The medium to coarse sand layers are locally as thick as $4 \mathrm{ft}(1.2 \mathrm{~m})$. Also, thin calcite-cemented sand layers have been found at several locations (fig. 4). These indurated layers are 0.125 to 0.25 in. $(0.318-0.635 \mathrm{~cm})$ thick and spaced 5.12 to 5.9 in. (13-15 $\mathrm{cm})$ apart.

Some of the rhythmite deposits no longer show their original horizontal bedding (fig. 4). These materials were deposited on or around stagnant ice blocks. As the ice melted, the depositional units collapsed; an example occurs at the North Springfield Reservoir. Most of these rhythmites dip toward the failure face.

Ground-water flow within the rhythmite sequences was mainly in the light-colored silt and sand layers. These silts and sands dominated as aquifers because the clayeysilt layers had lower hydraulic conductivities and acted as small confining beds. When fresh rhythmite surfaces were exposed, either by scraping off surface material or by digging small pits into the face, water would leak from the silt and sand layers. As water traveled through any of the silt and sand layers, it slowly saturated and weakened the silty-clay layers. 


\begin{tabular}{|c|c|c|c|c|c|}
\hline \multirow{3}{*}{\multicolumn{3}{|c|}{ TYPE OF MOVEMENT }} & \multicolumn{3}{|c|}{ TYPE OF MATERIAL } \\
\hline & & & \multirow{2}{*}{ BEDROCK } & \multicolumn{2}{|c|}{ ENGINEERING SOILS } \\
\hline & & & & Predominantly coarse & Predominantly fine \\
\hline \multirow{3}{*}{ SLIDES } & ROTATIONAL & \multirow{3}{*}{$\begin{array}{l}\text { FEW } \\
\text { UNITS } \\
\overline{M A}-\bar{N} \overline{-} \\
\text { UNITS }\end{array}$} & Rock slump & Debris slump & Earth slump \\
\hline & \multirow{2}{*}{ TRANSLATIONAL } & & \multirow{2}{*}{$\begin{array}{l}\text { Rock block slide } \\
\text { Rock slide }\end{array}$} & \multirow{2}{*}{$\begin{array}{l}\text { Debris block slide } \\
\text { Debris slide }\end{array}$} & \multirow{2}{*}{$\begin{array}{l}\text { Earth block slide } \\
\text { Earth slide }\end{array}$} \\
\hline & & & & & \\
\hline \multicolumn{3}{|c|}{ LATERAL SPREADS } & Rock spread & Debris spread & Earth spread \\
\hline \multicolumn{3}{|c|}{ FLOWS } & $\begin{array}{l}\text { Rock fiow } \\
\text { (deep creep) }\end{array}$ & \multicolumn{2}{|c|}{ (soil creep) } \\
\hline \multicolumn{3}{|c|}{ COMPLEX } & \multicolumn{3}{|c|}{ Combination of two or more principal types of movement } \\
\hline
\end{tabular}

Figure 3. Classification of slope movements (from Varnes, 1978). The terms "Few units" and "Many units" beneath the "Type of movement" column refer to the degree of disruption in a slide; for example, a few blocks or many blocks.

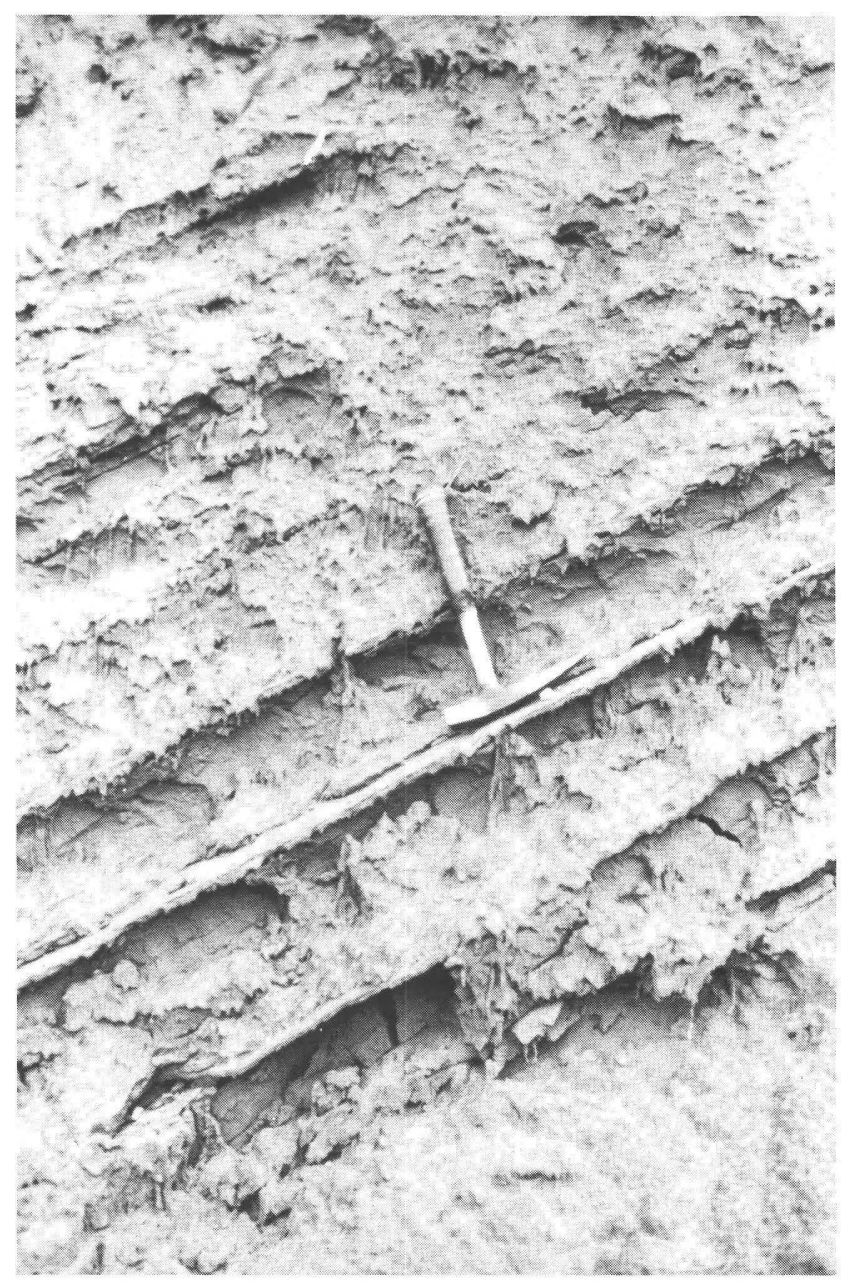

Figure 4. The Glacial Lake Hitchcock rhythmite deposit at the North Springfield Flood-Control Reservoir. The deposit is dipping to the west (left side of photograph) and has several calcite-cemented sand layers (hammer rests on one of these).
In situ field strength measurements were taken in the above sediments using torvanes and pocket penetrometers (table 2). The moisture content, as determined in the field and based on visual procedures (American Society for Testing Materials, 1985), of the samples tested ranged from moist to wet-moist indicates damp but no visible water, wet indicates visible free water; no tests were run on completely dry materials. The field tests (table 2) indicated that some of the materials involved in sliding had relatively uniform engineering characteristics throughout their total thickness, as shown by penetrometer readings (unconfined compression). At the North Hartland and the North Springfield Dam sites, the silty-sand, clayey-silt, and siltyclay layers had penetrometer readings that averaged 3.16 tons per square foot (3.16 kilograms per square centimeter). The low-cohesion fine sand at the U.S. Route 5 site at Windsor (fig. 1, locality 12) had an average penetrometer reading of 1.2 ton $/ \mathrm{ft}^{2}\left(1.2 \mathrm{~kg} / \mathrm{cm}^{2}\right)$, and the clays at the Vermont Route 11 site at Springfield (fig. 1, locality 10) had an average of $0.3 \mathrm{ton} / \mathrm{ft}^{2}\left(0.3 \mathrm{~kg} / \mathrm{cm}^{2}\right)$.

Overall, the shear resistance (undrained shear strength) for all the materials was low; silty-clays and clays that had some silt content had greater cohesion and a higher shear strength than other slide materials; for example, cohesive clay and silt at North Springfield site No. 1 had an average vane shear of 0.545 ton $/ \mathrm{ft}^{2}(0.545$ $\left.\mathrm{kg} / \mathrm{cm}^{2}\right)$, and the brown clay and some silt at North Hartland site No. 1 averaged 0.423 ton $/ \mathrm{ft}^{2}$ ). Vane shear readings (table 2) showed a zone of very low shear resistance $34.5 \mathrm{ft}(10.5 \mathrm{~m})$ below the top of the head scarp in the rhythmite section at North Hartland site No. 1; the crossbedded sand stratum in the rhythmite section was the thickest measured at the dam, and, as indicated in table 2, it was subject to piping. The average torvane reading for the zone referred to above was $0.038 \mathrm{ton} / \mathrm{ft}^{2}$ $\left(0.038 \mathrm{~kg} / \mathrm{cm}^{2}\right)$. This material was sandy, containing very 
Table 2. Torvane and penetrometer tests taken in four glacial lake-bottom deposit sites in Windsor County, Sharon excluded $[\mathrm{T} / \mathrm{S} / \mathrm{F}$ (ton per square foot) is numerically equivalent to kilograms per square centimeter using these instruments]

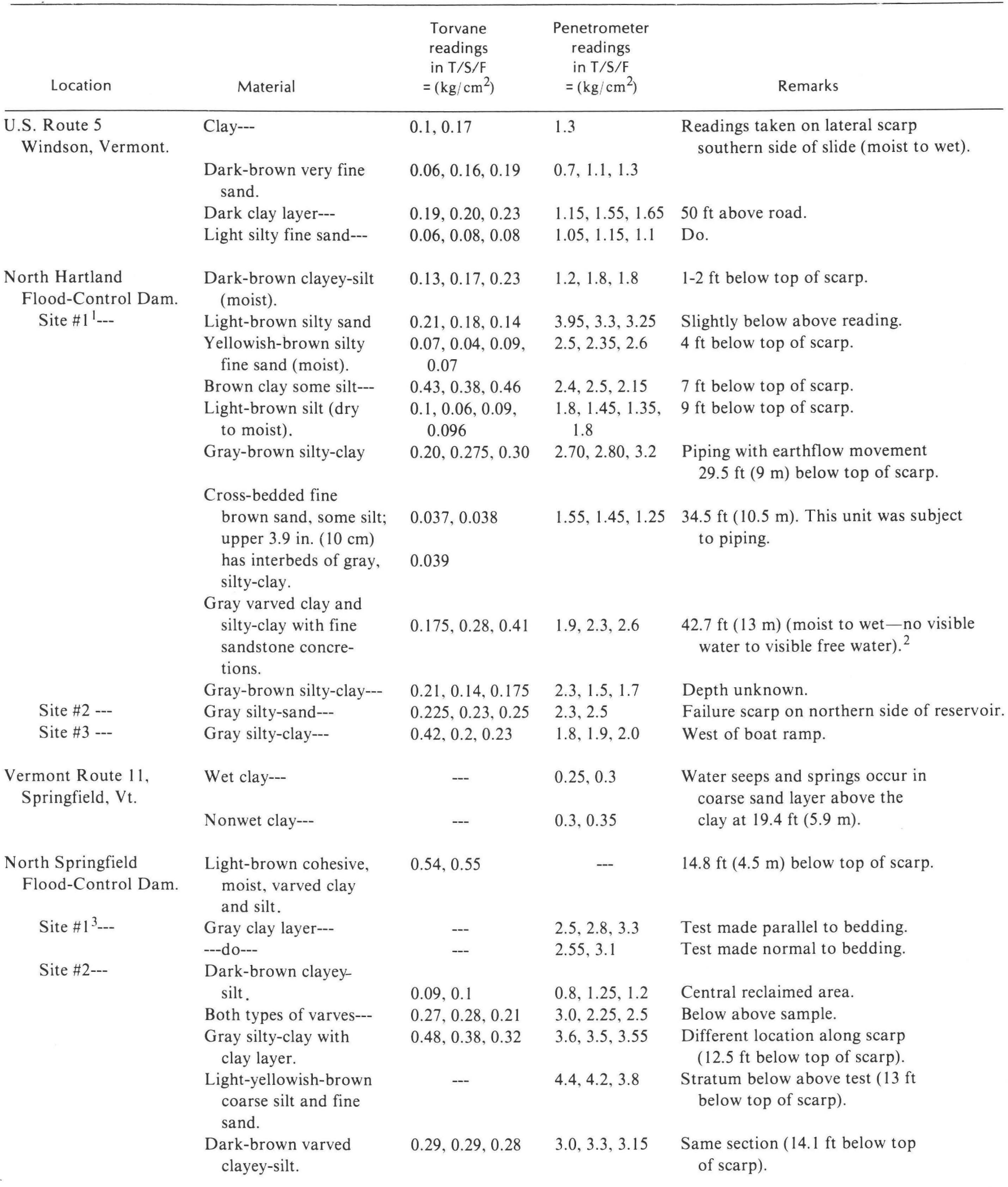

\footnotetext{
I On south side of reservoir, $1,115.5 \mathrm{ft}(340 \mathrm{~m})$ west of intake tower at toe of dam and near boat ramp parking lot.

${ }^{2}$ American Society for Testing Materials, (1985, Designation D2488 in Annual Book of American Society for Testing Materials Standards, sect. 4. v. 04.08, Soil and Rock; Building Stones-see table 3, p. 415).

${ }^{3}$ On eastern side of reservoir 4,593.4 ft (1,400 m) north-northeast of intake tower north-northeast and across reservoir east-southeast of boat ramp.
} 
little clay, which gave the layer a very low cohesion. After the earth flow occurred, this unit was piped extensively by ground water escaping from the scarp along the length of the layer (fig. 5). The high water conductivity through these sandier layers and parallel to the surfaces of the clay layers helped add water to the ultimate failure surface.
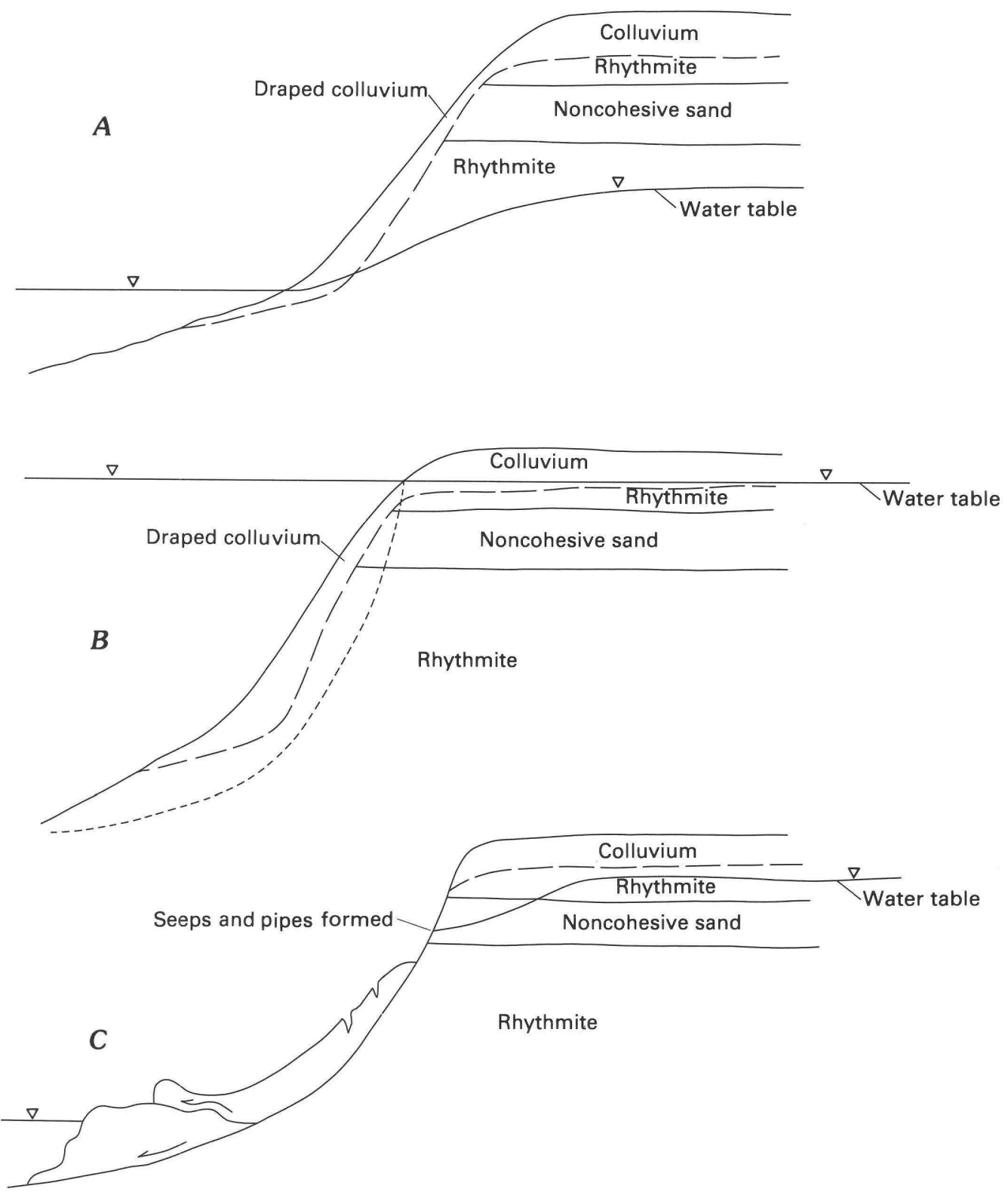

Figure 5. A typical flood-reservoir slope configuration in which earth-flow and piping failures have developed. A, Preflooding configuration. $B$, Flood stage. C, Postslide and piping configuration. The inverted delta symbol indicates the water surface. The sketches are not drawn to scale. 
Earth flows were the landslide type most commonly associated with the glacial lake deposits. Some of these slope movements had rotational or slump-type movement in the scarp area (slump-earth flow), and others had translational or block slide types of movement. The rhythmite deposits generally contained only minor amounts of gravel and larger detrital fragments. Slope movements occurring in these units were predominately in fine-grained materials, best classified as earth (Varnes, 1978). In many examples, some gravelly eskers underlie the lake-bottom deposits. Although some of these esker materials became incorporated into the lower parts of the slide mass, they had little or no effect on the overall earthflow character of the slide material (for example, the Sharon site discussed in the section "Sharon Slope Failure," consisted of lake-bottom sediments overlying a gravelly deposit, but the earth-flow aspect was maintained during the event).

\section{North Hartland Flood-Control Reservoir}

Many earth flows, some having piping failures, occurred along the rims and walls of tributary stream channels emptying into the North Hartland Reservoir (figs. 1, 5, 6). Earth flows with piping failures are treated separately in this section.

Gary Wheeler, U.S. Army Corps of Engineers assistant project manager (personal commun., 1984), reported that, during the 1984 flood stage in the reservoir, seiches observed on the water surface were due to subaqueous landslides upstream. It was stated that the sound from upstream was audible at the dam.

\section{Earth Flows}

A slide located on the northeastern valley wall of the reservoir (fig. 7) near the North Hartland Dam emergency spillway was an example of the slump-earth flows encountered. This slope movement occurred in spring 1984 along the face of a terrace that formed the northeastern valley wall. An unnamed stream flows southwestward into the reservoir from the west flank of Miller Hill (fig. 1, locality 11; A in fig. 6) along the base of the terrace. The toe of the failure temporarily blocked the stream, but, by eroding the toe, the stream has reoccupied its original channel.

The slope failure had a differential elevation of 110 $\mathrm{ft}(33.5 \mathrm{~m})$ from the head scarp to the toe at the unnamed stream level. The toe of the failure was stopped by the stream channel just before reaching the lake. The failure length was about $580 \mathrm{ft}(176.8 \mathrm{~m})$ from the head scarp to the toe along the axis of sliding and was $475 \mathrm{ft}(144.78 \mathrm{~m})$ wide normal to the axis. The upper boundary of this

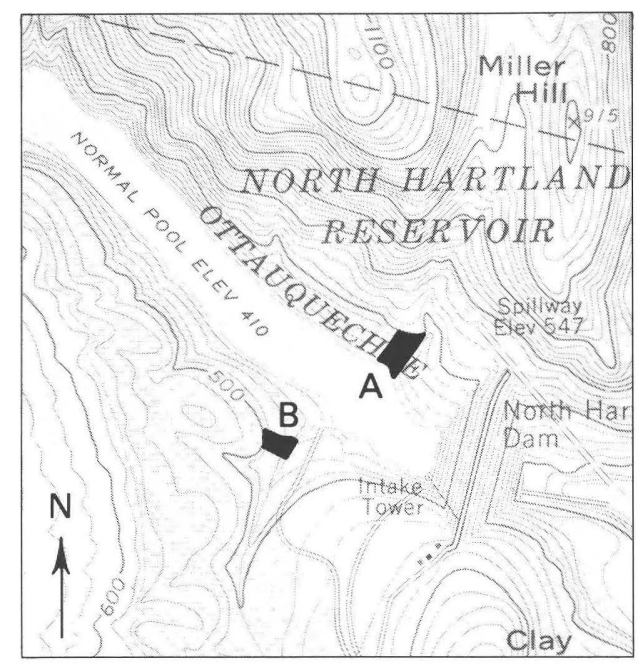

Base from U.S. Geological Survey 1:24 000 North Hartland, 1959

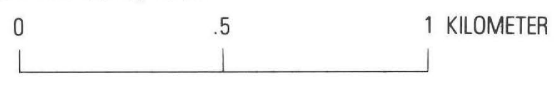

CONTOUR INTERVAL 20 FEET

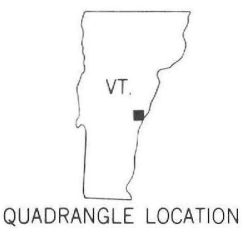

Figure 6. The North Hartland FloodControl Reservoir slide area. The slide at A is on the northeastern side of the reservoir with the unnamed stream valley on the eastern edge. The slide at B is just southwest of the boat ramp.

failure was marked by two undulating scarps. The two scarps (main and minor) had vertical offsets of $2.5 \mathrm{ft}(0.76$ $\mathrm{m}$ ) each and horizontal tension openings of 4 to $9 \mathrm{in}$. $(10.16-22.86 \mathrm{~cm})$. The slope angle of the scarps ranged from $50^{\circ}$ to $62^{\circ}$ (119-188 percent). Slickensides were observed on clay-smeared fresh scarps in July 1984 (fig. 8), but they were eroded gradually by subsequent rainstorms.

The eastern side of the failure mass (just out of view on the right side of fig. 7) had numerous en echelon transverse tension gashes and small vertical displacements. The western side of the mass was bounded by an irregular, curving scarp and one or more lateral shear planes. Except for some tension cracks, the central portion of the slope movement had a relatively smooth upper surface.

The lateral tension cracks seen in the left foreground of figure 7 resulted from an increase in friction on the basal shear surface of the failure as the fluidized substrate pinched out, placing the basal shear surface in direct contact with the sole of the slide mass. This caused drag on the sole of the slide mass pulling it apart (extension) as shown in figure 9. Drag on the basal shear surface in the head scarp area generated tension crack openings (tensile 


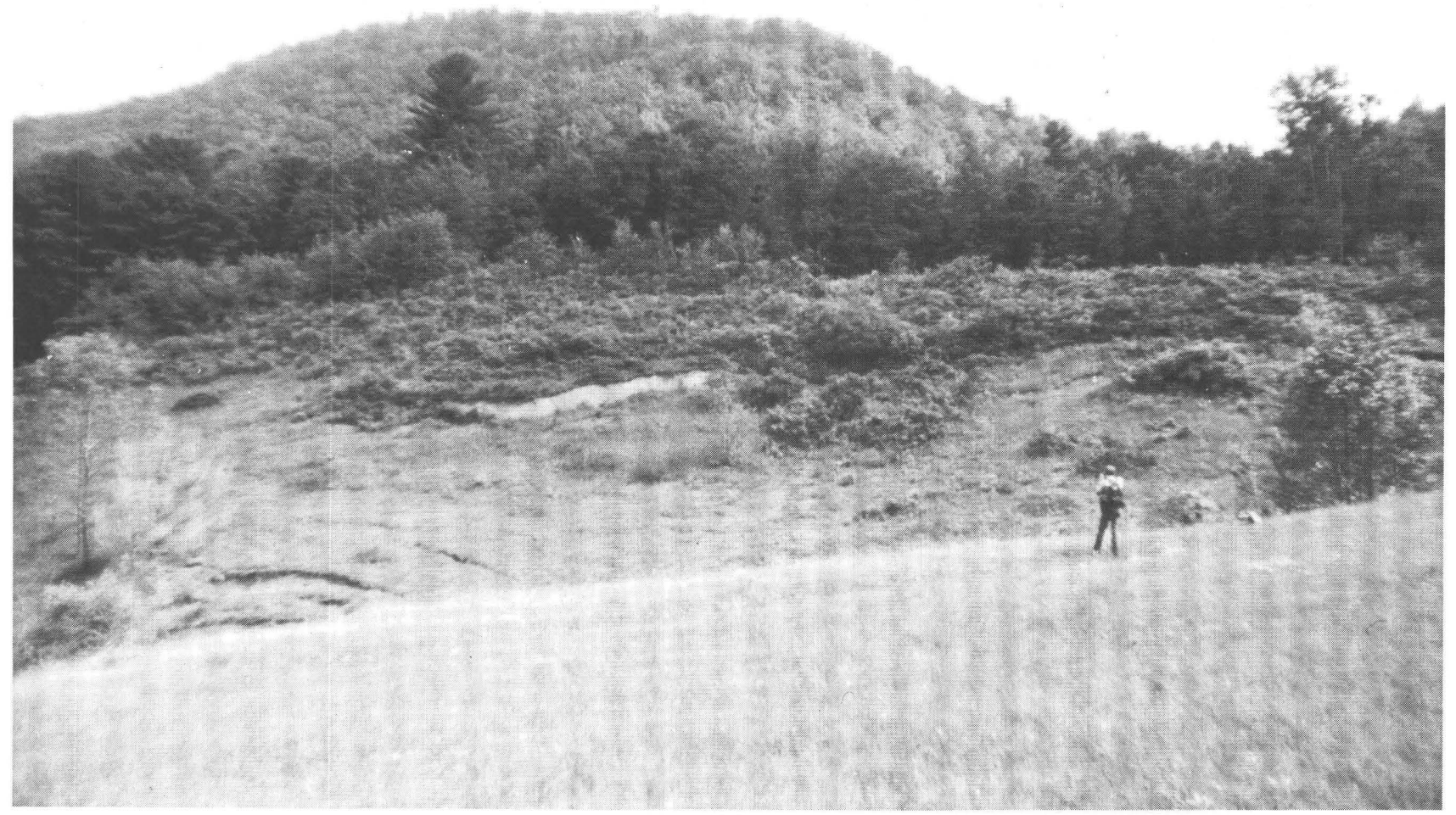

Figure 7. Slope movement on the northeastern wall of the North Hartland Flood-Control Reservoir west of the spillway. The head scarp is in the center. Tension cracks on the midsection of the flow can be seen on the lower left. The shrubs on the lower left were mud coated due to the high water during reservoir flooding. The smooth area in the foreground is the edge of a grass-covered hill on the southeastern side of the unnamed stream valley from which the photograph was taken.

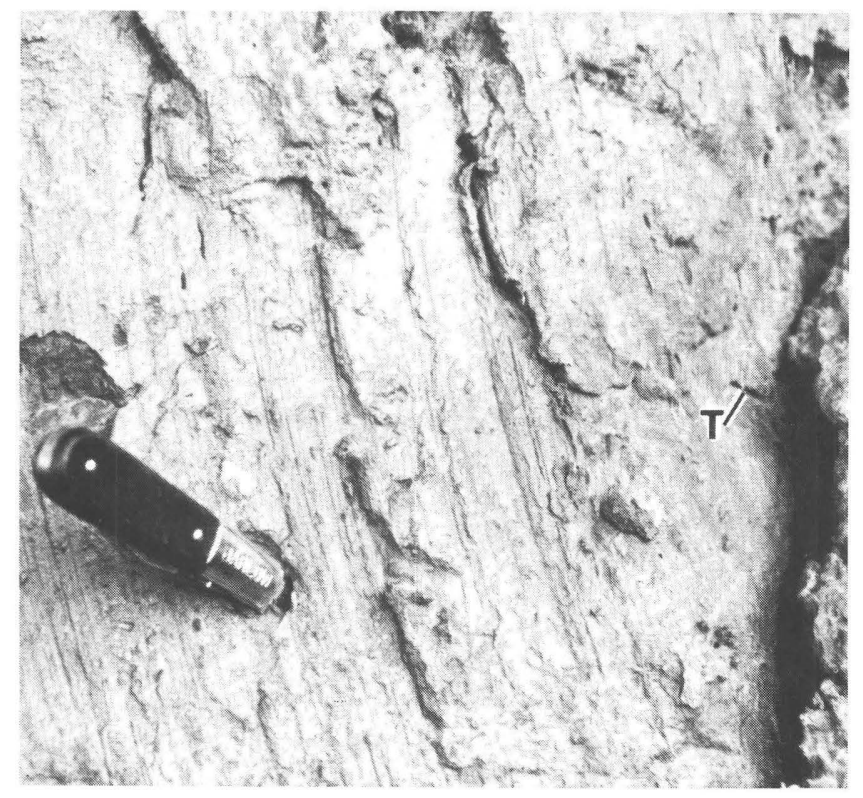

Figure 8. Slickensides on a clay-smeared head-scarp surface of the slump-earth flow on the northeastern valley wall of the North Hartland Flood-Control Reservoir. T is the location of a horizontal tension crack. stress) normal to the direction of movement during sliding as shown at $\mathrm{T}$ in figure 8 . The entire upper surface of the slide mass has undergone some extension in the direction of movement. Hummocks and lobes of slide material formed the distal part of the toe of this earth flow. Tension cracks also were found throughout the toe area.

A secondary earth flow developed within the toe area of the main movement. This failure occurred along the western side of the main earth flow where the valley of the unnamed stream widened. The toe of the secondary failure separated into small blocks of intact material riding on a layer of fluidlike material. As the blocks came to rest, the fluid material oozed from below the blocks.

In the upper part of the slide mass near the head scarp, the basal zone of liquified material pinched out and was replaced by a planar failure surface (fig. 9). In the head scarp area of these earth flows, some small minor rotational slumps that were separate from the main failure mass were seen.

Failure in both earth flows appeared to have occurred as rafts of intact material riding on layers of fluidized material. Some of the tension cracks referred to above were caused by the extension of the failure mass as discussed previously, but others could have been caused 


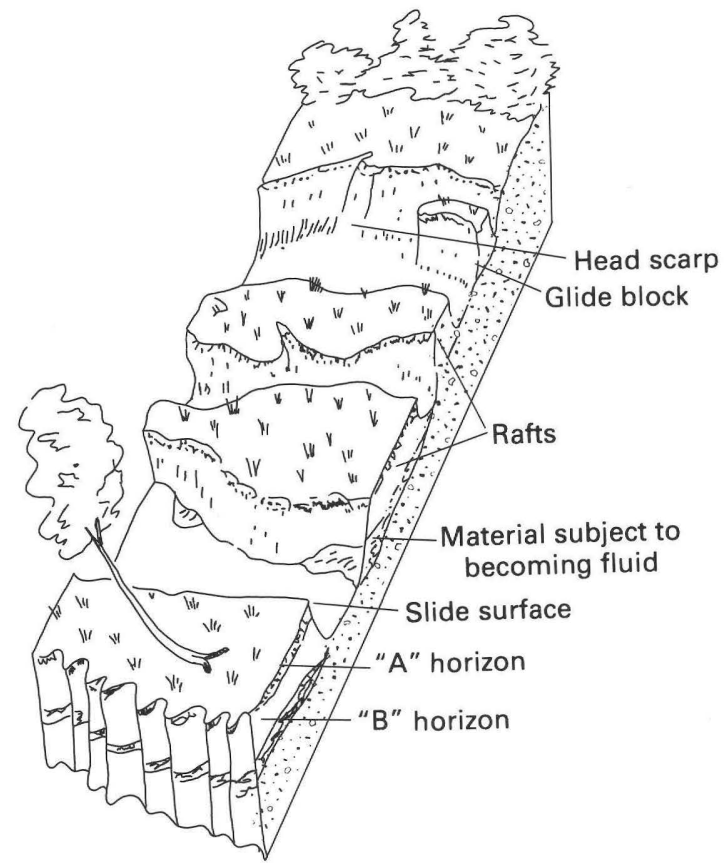

Figure 9. Rafts of intact material sliding on a fluidized substrate that pinches out headward. The failure surface above the pinchout point becomes a planar frictional surface. This friction creates a pulling apart of the slide material on tension cracks; as a result, some separated glide blocks developed. This sketch is not drawn to scale.

by the bulging and buckling of the surface of the slide mass in the toe area as material piled up.

\section{Piping Associated With Earth Flows}

Of the many landslides that occurred on the southwestern valley wall of the North Hartland Reservoir, one in particular, just west of the boat ramp parking lot, had piping associated with the failure (fig. 10). The site, a terrace, consisted of a rhythmite sequence covered by a layer of colluvium. Near the top of the terrace, the rhythmite sequence was interrupted by a 4 -ft (1.2-m)-thick medium sand layer. The noncohesive sand layer, which had a higher hydraulic conductivity than the surrounding rhythmites, acted as a confined aquifer as shown in figure 5 .

As the water in the reservoir rose during spring 1984, it flowed into and through the colluvium and into the sand layer and the rhythmite sequences by way of their silt layers. Eventually, water within the confined sand reached a hydrostatic head roughly equal to the height of the reservoir pool above the confined sand layer. As the water level in the reservoir dropped, the colluvium above the rhythmite sequence maintained a perched water table, and the confined sand layer of medium grain size held water similar to an artesian aquifer.
The slope failed as an earth flow, which was partially fed by water from the confined sand layer as well as from the saturated colluvium (fig. 5). The material involved in the failure included the colluvial cover along the slope face as well as some of the rhythmite sequence. It moved as a rapid fluid earth flow across a stream channel and was stopped by the parking lot embankment (fig. 10, foreground). The failure removed the colluvial cover, which exposed the confined sand layer and allowed the remaining water to escape from this layer. Because the sand had lower cohesion than the surrounding rhythmites, it was removed by the escaping water. Pipes as much as approximately $4 \mathrm{ft}(1.2 \mathrm{~m})$ in diameter developed (A in fig. 10). Most of this movement occurred in rapid succession; the initial earth flow was followed closely by the piping phase.

From this example, it was apparent that groundwater flow in the slopes around the North Hartland Reservoir had a major effect on slope movement. When the reservoir filled, the ground-water table rose with it. As the reservoir level was drawn down, the then higher level ground water flowed toward the reservoir and exited the slope above normal pool level for some time (fig. 5). A high moisture content was still evident in the sand unit associated with the pipes. This ground-water flow generated high water pressure on the potential slide surface (see Costa and Baker, 1981). Slope movement initiation occurred through the increased pressure head created by this new ground-water configuration.

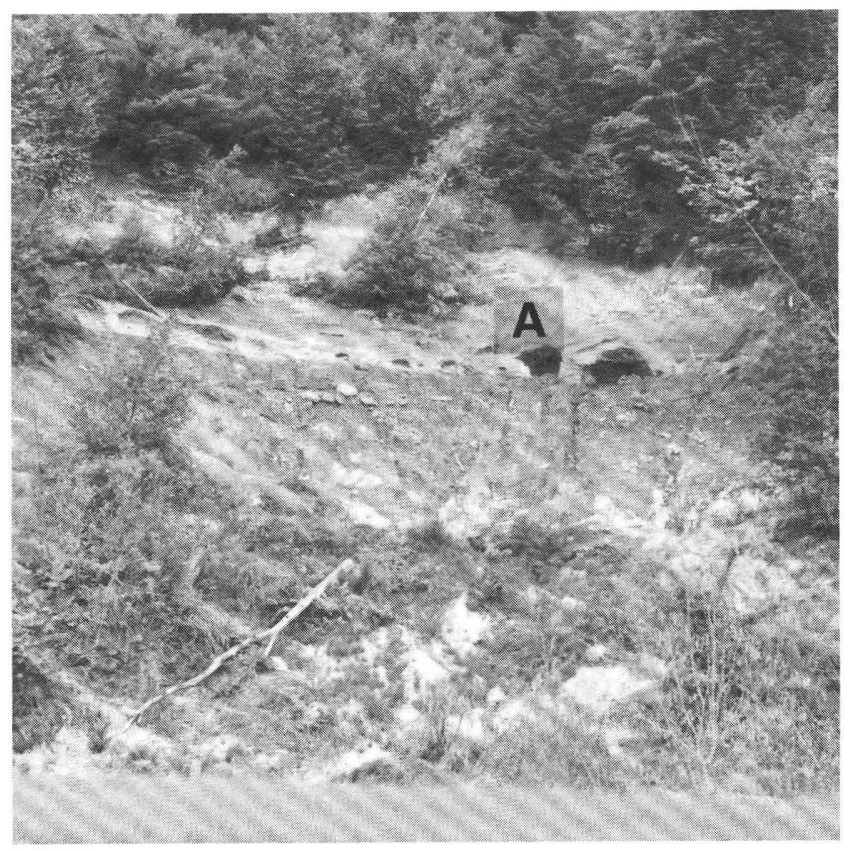

Figure 10. Part of the southwestern valley wall of the North Hartland Flood-Control Reservoir showing piping cavities (A) in a sand layer confined between two rhythmite sequences. These cavities are up to $3.9 \mathrm{ft}(1.2 \mathrm{~m})$ in diameter. 


\section{Vermont Route II}

Another earth flow in glacial lake-bottom deposits developed along Vermont Route 11, southeast of the town of Springfield (fig.1, locality 10; fig. 11). The failure occurred on the face of an 80-ft (24.4-m)-high terrace on the southwestern wall of the Black River valley. Because the failure did not involve the present new alignment of Route 11, no corrective measures were taken, except for the removal of trees on the slide mass that threatened power and telephone lines.

The terrace deposits consist of a medium to coarse sand overlying a rhythmite sequence. The subhorizontal terrace surface is $100 \mathrm{ft}(30.5 \mathrm{~m})$ wide back to front. The slope angle of the terrace front is $42^{\circ}$ ( 90 percent), and $\mathrm{the}$ hill slope angle behind the terrace is $34^{\circ}$ (67 percent).

Numerous springs issue from the bedrock hill above the terrace. The terrace surface has a slight slope back toward the bedrock-defended hill. A small stream drains the swamp area along the proximal side of the terrace surface and runs in an easterly direction parallel to the bedrock hill. Water from these springs also soaks into the terrace sediments and reemerges as springs on the terrace front (fig. 12). In a trench excavated in the scarp face to

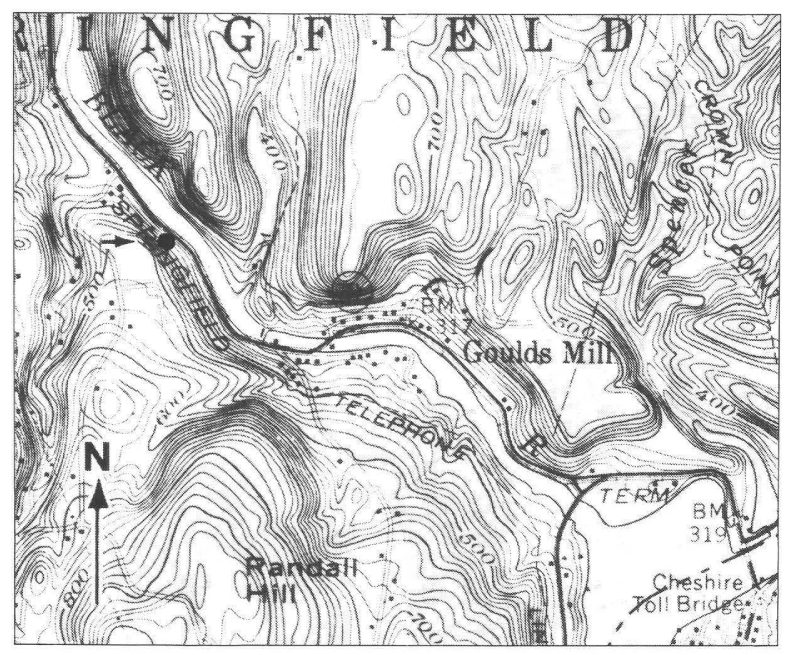

Base from U.S. Geological Survey 1:62 500 Claremont, N.H.-VT. 1957

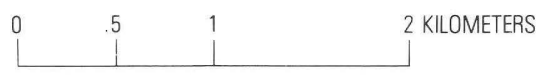

CONTOUR INTERVAL 20 FEET

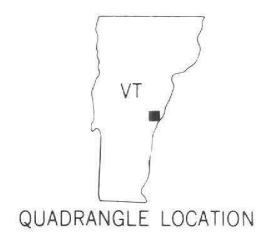

Figure 11. The Vermont Route 11 slide. Slide is in the upper left of the map at the arrow.

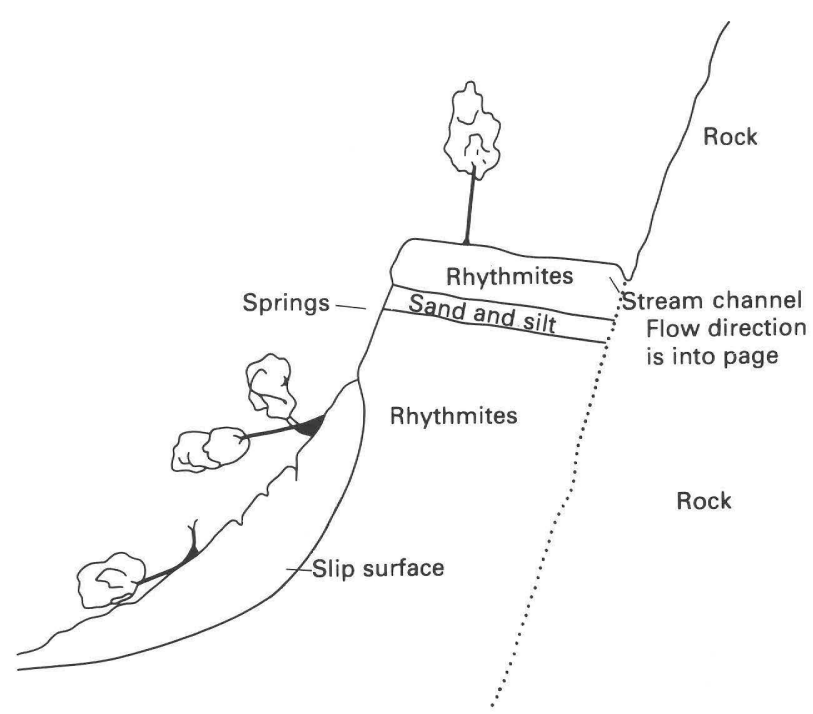

Figure 12. The terrace configuration at the Vermont Route 11 landslide site near Springfield showing strata and water-flow direction. This sketch is not drawn to scale.

obtain a clean exposure of the rhythmite sequence, water flowed from the silty sand layers.

Many features of this failure were similar to those described in the section "North Hartland Flood-Control Reservoir." The head scarp measured $12 \mathrm{ft}(3.66 \mathrm{~m})$ vertically and $140 \mathrm{ft}(42.67 \mathrm{~m})$ across normal to the slide axis. The scarp had a steep face, and the failure moved along a single slide plane in the head-scarp area; some rotation also was noted. The surface of the failure mass had separated into discrete blocks.

The toe crossed what had been the original alignment and remnant pavement of Route 11. The material in the toe, including blocks containing trees, flowed out over the old pavement without disturbing it. A fluid mass of graybrown silt came out from under the failed mass and spread over the old road beyond the toe. It was apparent to the authors that the main slide mass moved on a fluidized zone. This fluid layer was fed by seeps issuing from the terrace face at the water-table level. Water still was flowing from the failure mass onto the old road at a volume equivalent to a very small creek when the failure was examined in mid-July 1984.

After the movement, trees on the slide mass were cut down, ostensibly to prevent their interference with communications lines crossing the site normal to the slide axis should sliding commence again. Examination of tree rings from the stump of one of these cut trees showed that this area had prior creep movement. During a few years on either side of 1950, the tree rings indicated that asymmetric growth developed, which suggested a period of stress for the tree when the slope may have slipped a bit or at least developed accelerated creep. 
The slopes on Route 11 that had not failed showed signs of creep, and the pipestem tree trunk structure was common. Phipps (1974) suggested that the leaning or curving of tree trunks was the result of geotropic response of the trees. Sharpe (1938) indicated that bent tree trunks may be one of the indicators of slow flowage or creep on slopes. Tree spacing was such that phototropic response could not be a satisfactory answer for the number of trees with these shapes on the unfailed adjacent slopes as well as on the one that failed.

Penetrometer tests showed that the rhythmites had extremely low compressive strength. The silt layers yielded readings of 0.3 ton $/ \mathrm{ft}^{2}\left(0.3 \mathrm{~kg} / \mathrm{cm}^{2}\right)$, compared to the average of $2.5 \mathrm{ton} / \mathrm{ft}^{2}\left(2.5 \mathrm{~kg} / \mathrm{cm}^{2}\right)$ for silts tested in other slope-movement areas. Low compressive strength readings at this location may have been the result of the soils being wetter than those encountered at other sites.

\section{U.S. Route 5}

The site of this landslide was located in the Connecticut River valley on the western side of U.S. Route 5 on the eastern slope of Horseback Ridge just south of the town of Windsor (fig. 13). The slope failed just after the heavy rains at the end of May 1984. The head scarp had cut halfway across an old overgrown road that runs parallel to Route 5 about $110 \mathrm{ft}(33.5 \mathrm{~m})$ upslope. The slope angle below the old road and along the slide axis measured $30^{\circ}$ ( 58 percent), and the slope angle above the old road was $36^{\circ}$ (73 percent).

Several old landslide scars were seen to the south of this failure. All the head-scarp crowns were at the same elevation. This elevation defined a terrace level that extended to the east of the old road in a southerly direction.

From the top down, the stratigraphy of the Route 5 slide is as follows. The topsoil was a spongy dark-brown to black silty clay and had about 40 percent fine mica; this layer was about $1 \mathrm{ft}(0.30 \mathrm{~m})$ thick. Beneath the topsoil was 31.5 in. $(0.80 \mathrm{~m})$ of rhythmically bedded sticky gray clay, and very fine dark-brown sand containing about 30 percent silt; the top 6 in. $(0.15 \mathrm{~m})$ of this horizon was saturated. The sand layers were damp but showed no visible water; the clay showed visible water at the time of observation. The next soil unit below contained a fine to medium brown sand that had about 30 percent silt and fine pea gravel. Beneath this layer, which is about $10 \mathrm{ft}$ (3

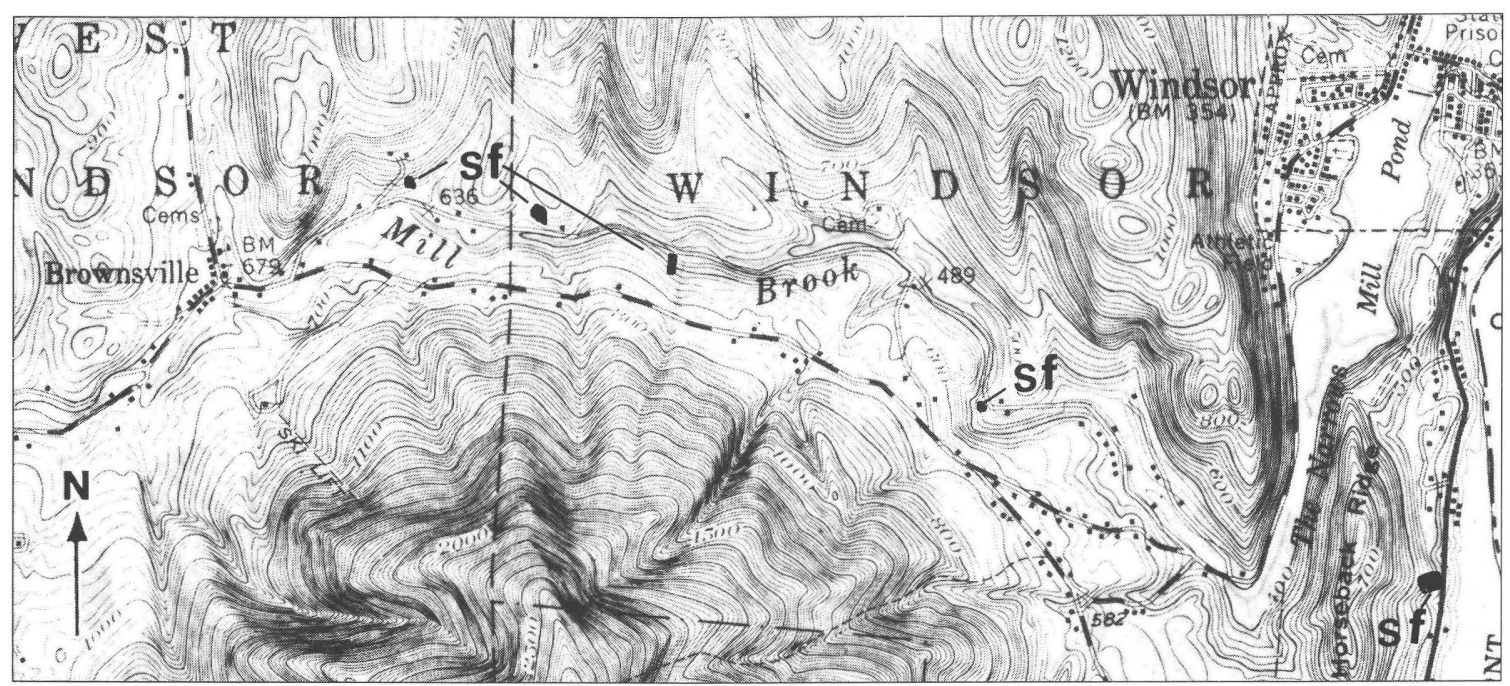

Base from U.S. Geological Survey 1:62 500 Claremont, N.H.-VT. 1957
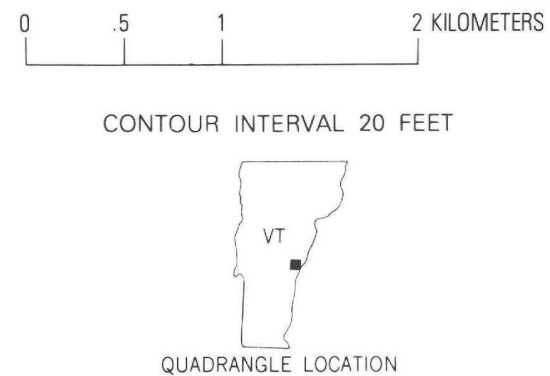

Figure 13. The Route 5 and Brook Road slides (fig. 1, localities 2, 18 slides). The slope failures are designated by "sf." 
m) below the top of the scarp, was a saturated dark-brown gravelly fine sand and silt. The toe material was a brown to gray silt and clay quite churned up from the sliding.

When we examined the site on July 24 , the saturated failed toe area still was exuding water. Springs were noted to be issuing from numerous locations at the base of the head scarp and in the scarp areas of the older landslides to the south. These springs marked a level along this entire slope just below the terrace top that defined the contact between an upper aquifer composed of the dark-brown gravelly fine sand and a lower layer of gray clay, which was observed in the failed head scarp. Heavy flow from these springs after intense precipitation apparently triggered the slides.

Torvane tests taken in the sticky gray clay were 0.10 to 0.17 ton $/ \mathrm{ft}^{2}\left(0.10-0.17 \mathrm{~kg} / \mathrm{cm}^{2}\right)$, and the penetrometer gave a reading of $1.3 \mathrm{ton} / \mathrm{ft}^{2}\left(1.3 \mathrm{~kg} / \mathrm{cm}^{2}\right)$, indicating very low shear resistance and compressive strength. The darkbrown fine sand, which was weaker, had torvane readings of 0.06 to 0.19 ton $/ \mathrm{ft}^{2}\left(0.06-0.19 \mathrm{~kg} / \mathrm{cm}^{2}\right)$ and penetrometer readings of 0.07 to $1.3 \mathrm{ton} / \mathrm{ft}^{2}\left(0.7-1.3 \mathrm{~kg} / \mathrm{cm}^{2}\right)$.

The Route 5 slide was an earth flow. The flow mass had a width that varied from 150 to $200 \mathrm{ft}$ (45.7-61 m) and was not channelized. No tension gashes were noted as in other slides of this type; for example, North Hartland. Some slickenslides were visible on lateral scarps and the head scarp. Good evidence for this event having been a flow was the nondescript slushlike toe material that still was issuing water weeks after the slide. Trees on the surface of the slide mass ranged from saplings to 12 to 36 in. $(30.5-91.4 \mathrm{~cm})$ in diameter at breast height; most of these had a pipestem trunk structure, indicating long-term creep on the slope.

\section{North Springfield Flood-Control Reservoir}

Since the first filling of the North Springfield Reservoir in 1960, slope movements of serious proportions have been occurring due to floods that year and all subsequent such events (Michael Curran, U.S. Army Corps of Engineers, oral commun., 1984). Slope movements also occurred before construction of the reservoir, as evidenced by pre-1960 landslide sites. Trees on these earlier landslide sites showed creep evidence based on pipestem structure and that their convex sides faced downslope near the bases of their trunks. Eroded slide scarps were also present. Of the many old landslides that predate the construction of the flood-control system, some were reactivated in 1984 .

Three older landslide areas of the eastern slope within the flood pool of the reservoir had been stabilized by the U.S. Army Corps of Engineers. This stabliization was acccomplished by grading the slope back to an angle of $26^{\circ}$ (approximately a 2 on 1 slope) and the planting of selected types of vegetation. The southern part of the eastern slope was stabilized in two stages beginning in fall 1975 and completed in summer 1976; the northern part of this slope was stabilized in 1980 (Thomas Coen, U.S. Army Corps of Engineers Project manager, oral commun., 1985). However, these slopes were reactivated, and numerous new slides were activated elsewhere in the basin (fig. 14) in spring 1984.

The failures at the North Springfield Reservoir can be best classified as earth flows that had some local variations. Two special features found at North Springfield were the configuration of the slide toes and the nature of

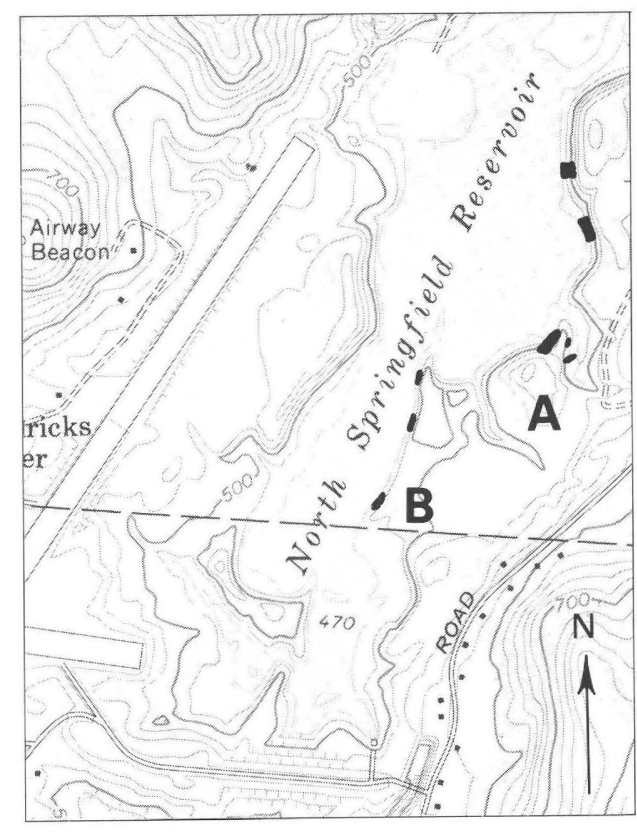

Base from U.S. Geological Survey 1:24 000 Chester, 1972

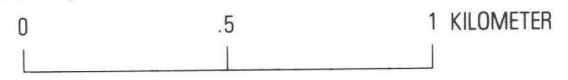

CONTOUR INTERVAL 20 FEET

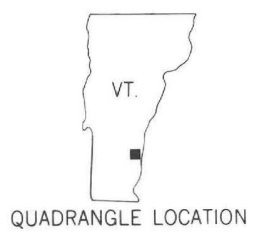

Figure 14. The North Springfield FloodControl Reservoir slide area. The location of the slide on the eastern side of the reservoir at which changes of attitude of the deposit were noticed over the slide length is designated by $A$. The site of the Corps of Engineers slope stabilization project is shown by $\mathrm{B}$. 
the deposit. The deposit at one failure studied on the southeastern side of the reservoir (A in fig. 14) had a clayeysand, gravel, and silt layer at the top. These materials were probably stream deposits laid down after the level of Glacial Lake Hitchcok dropped. This would make the material that covered the slope face a reworked soil and (or) slope wash. A lake-bottom rhythmite sequence underlies these deposits for about $60 \mathrm{ft}(18 \mathrm{~m})$. This latter sequence overlays a coarse gravel, cobble, and sand unit. These lower deposits may be those of an esker. The attitude (or strike and dip) of this lower unit, and the overlying rhythmites, changed along the slope length from north to south as follows: N. $55^{\circ}$ E. dipping $30^{\circ} \mathrm{NW}$., N. $60^{\circ}$ E. dipping $9^{\circ} \mathrm{NW}$., and N. $20^{\circ}$ E. dipping $75^{\circ}$ E. These attitudes indicate collapse structures possibly caused by stagnant ice that subsequently melted beneath these deposits. An angular unconformity exists between the dipping rhythmite layers and the top clayey-sand, gravel, and silt strata.

The coarse gravelly bottom deposits provided a zone of high permeability and high shear resistance beneath the slide mass. As was the case with the piping failures at the North Hartland Reservoir, water entered the coarse materials when the reservoir level was high. When the lake level was lowered, these coarse deposits provided water to the overlying material that was involved in the failure. The coarse bottom deposits did not become part of the slide mass except for slight mixing along the contact; the sliding mass passed over these materials and left them almost intact.

Toes on failures at the North Springfield Reservoir were somewhat different from what was observed at the North Hartland Reservoir. At North Springfield, multiple ridges or hummocks of slide material were aligned parallel to the toe, whereas many of the toe areas at North Hartland had relatively smooth surfaces with en echelon tension gashes normal to the slide axis. At the site stabilized by the Corps of Engineers on the eastern valley wall ( $\mathrm{B}$ in fig. 14) closest to the dam, the hummocky toe consisted of a rigid layer that buckled upon sliding; small crevasses formed by the buckling became filled with finegrained fluidized material from beneath the flow (fig. $15 A$ ). This buckled layer had an appearance similar to a rug that has been pushed against a wall and folded.

The buckling in some of the toes appeared to go a step further, which probably was due to a greater velocity or a greater fluidity in the sliding material. As the distal part of the toe stopped moving, slide material in the main track behind the toe still would be travelling on a fluidized substrate. The still-moving mass then probably formed an overthrust sheet and ramped up onto the first sheet. This process apparently repeated itself several times (fig. $15 \mathrm{~B}$ ). At the leading edge of a thrust sheet, a linear trough occurred that was filled with material from the fluidized fine-grained substrate.

\section{Sharon Slope Failure}

The Sharon landslide is located in the White River valley on the eastern side of Vermont Route 14 about $2 \mathrm{mi}$ $(3.2 \mathrm{~km})$ north of the village of Sharon (figs. 1, 16). This valley has been modified into a U-shape by glacial erosion. While the glacier still occupied the valley, kames and eskers were deposited along the valley walls and bottom. After the glacier receded, the valley was occupied by Glacial Lake Hitchcock. Lake beds were deposited that had some deltaic sediments emplaced above them. The present valley configuration was established when the glacial lake drained and the White River eroded the lakebed sediments and other glacial deposits. The White River presently flows along bedrock in this section of the valley.

The failure occurred in a terrace deposit along the eastern valley wall. The stratigraphy of the terrace from the top down is as follows: 0 to $12 \mathrm{in}$. $(0-0.305 \mathrm{~m})$, lightbrown sandy loam; 12 to 24 in. $(0.305-0.610 \mathrm{~m})$, tan to grayish-tan silt, a slight trace of clay and very fine sand; and 24 to 30 in. $(0.610-0.762 \mathrm{~m})$, crossbedded fine to coarse light-brown sand, some fine to medium gravel. This unit varies in thickness parallel to the valley trend and shows definite foreset and bottomset beds. These deposits unconformably overlie about $56 \mathrm{ft}(17.1 \mathrm{~m})$ of rhythmically bedded gray silts and clays. Below the rhythmites is an esker deposit composed of stratified cobbly sand and gravel about $25 \mathrm{ft}(7.62 \mathrm{~m})$ thick.

The rhythmically bedded units at Sharon are Glacial Lake Hitchcock bottom sediments. The rhythmite units have a slight dip to the east and are displaced by reverse faults (fig. 17 $A$ ) that dip steeply to the west.

The sand units overlying the rhythmites are either deltaic deposits from a lake that formed later than Glacial Lake Hitchcock or stream sediments deposited on the rhythmite surface immediately after the lake drained. In either case, they fill in the low spot along the upper part of the terrace. The sand unit presents a cross section that has a concave bottom surface from west to east across the top of the terrace, similar to a section across a stream-channel filling.

Thin layers of late or post-Wisconsinan colluvium (Carl Koteff, U.S. Geological Survery, oral commun., 1984) are draped over the deltaic deposits and rhythmites. A discontinuous clay layer within the colluvium is stretched and, in some instances, pulled apart in boudinlike fashion. These structures are the result of tension in cohesive materials due to downslope creep (Weller, 1960).

Before the 1984 failure, two borrow pits had been excavated into portions of the terrace. The first of these had removed the esker sediments from the lower part of the terrace facing on Vermont Route 14 (fig. 17B). The other borrow pit was dug into the top of the terrace where the deltaic sediments were the excavated materials. Both pits were inactive when the failure took place. 

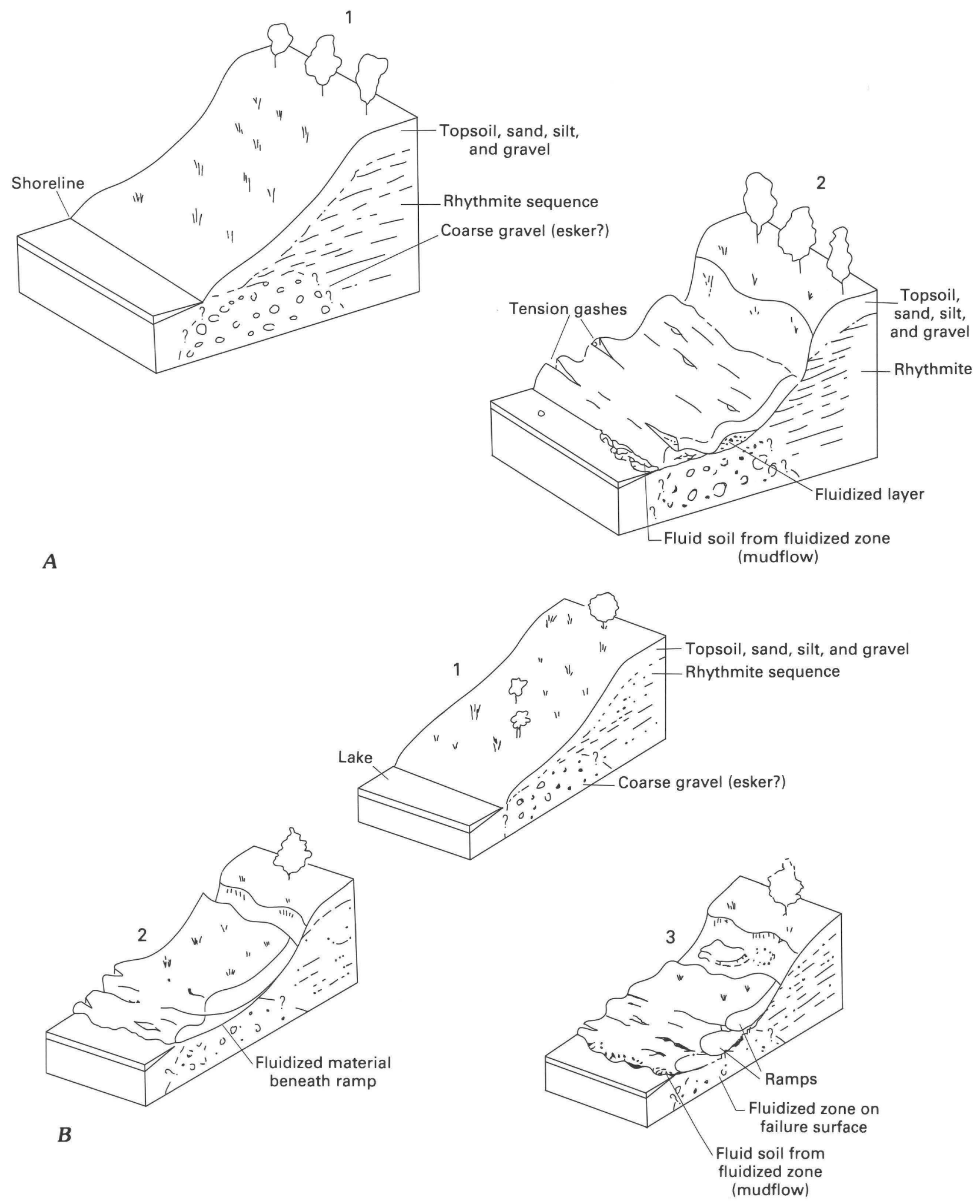

Figure 15. The processes for the formation of multiple ridges or hummocks at the eastern abutment of the North Springfield Dam. $A$, The hummocks developed in the intact layer are shown with the fine-grained fluidized material from beneath penetrating the cracks in the upper layer. $B$, Mode of overthrusting and ramping in the toe area of slope movements is shown. The numbers represent the order of the development of the failures. These sketches are not drawn to scale. 


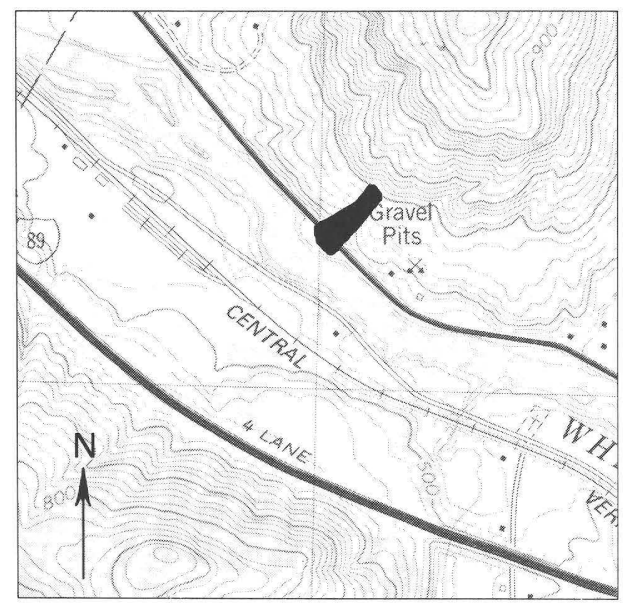

Base from U.S. Geological Survey 1:24000 Sharon, 1981

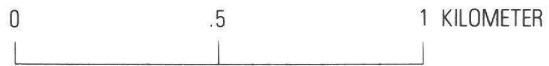

CONTOUR INTERVAL 20 FEET

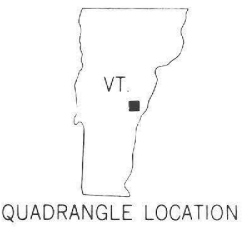

Figure 16. The Sharon slide area.

The width of the failure was approximately $100 \mathrm{ft}$ $(30.5 \mathrm{~m})$ across at the head scarp and about $250 \mathrm{ft}(76.2 \mathrm{~m})$ across at the toe. At the top, near the head scarp, blocks rotated in the sand units and the rhythmites (note tilted trees at right-centers of fig. $17 \mathrm{C}$ ). Also, in the slide mass are large chunks $[ \pm 3 \mathrm{ft}( \pm 0.9 \mathrm{~m})]$ of the rhythmite that failed and remained on the slope or near the point of failure as disoriented or jumbled blocks; a few of these have been rotated.

Before the excavation of the upper borrow pit, surface-water runoff flowed off the terrace and did not saturate the deltaic sediments. This was due, more than likely, to the colluvium, which has a low enough permeability to have acted as a protective cap. After excavation, the upper pit became a catchment basin, but no channel drained out. Water that was impounded in the pit saturated the sand unit above the rhythmic sequence, which acted as an impermeable bottom. As water in this pit deepened, it seeped through the rim and overflowed the rhythmite sequence, inundating the slope. Previously, evaporation and underflow drainage along the long axis of the pit, which slopes slightly southward, may have kept an equilibrium between inflow and outflow. However. intense rainfall in late spring 1984 may have saturated

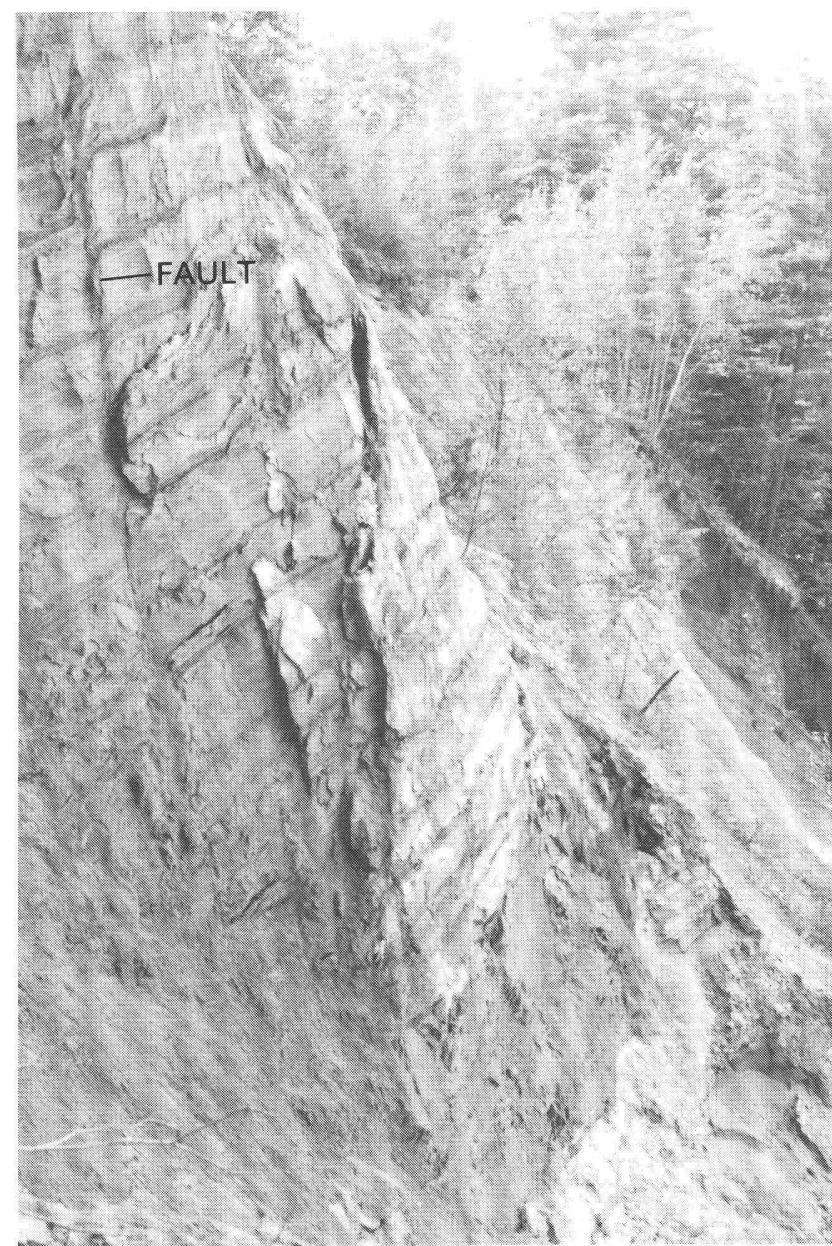

A

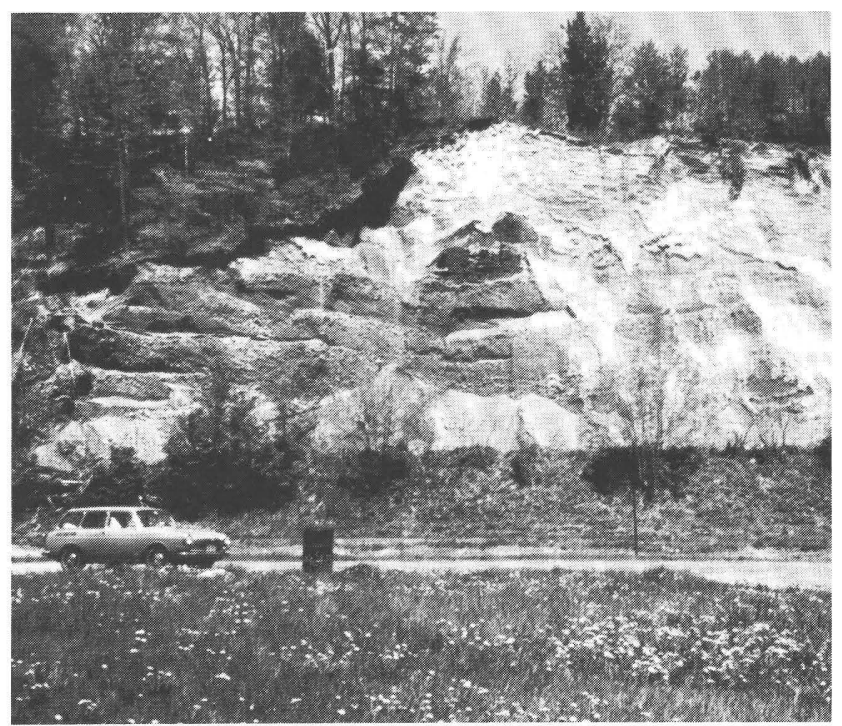

B

Figure 17. The landslide site north of Sharon on Vermont Route 14. A, This fault is one of several reverse faults exposed at this site. $B$, How the site looked as a borrow pit facing Route 14 before the failure. C, The breach channel that developed during the failure is seen to the left of center. (Photograph $B$ courtesy of Charles A. Ratté.) 


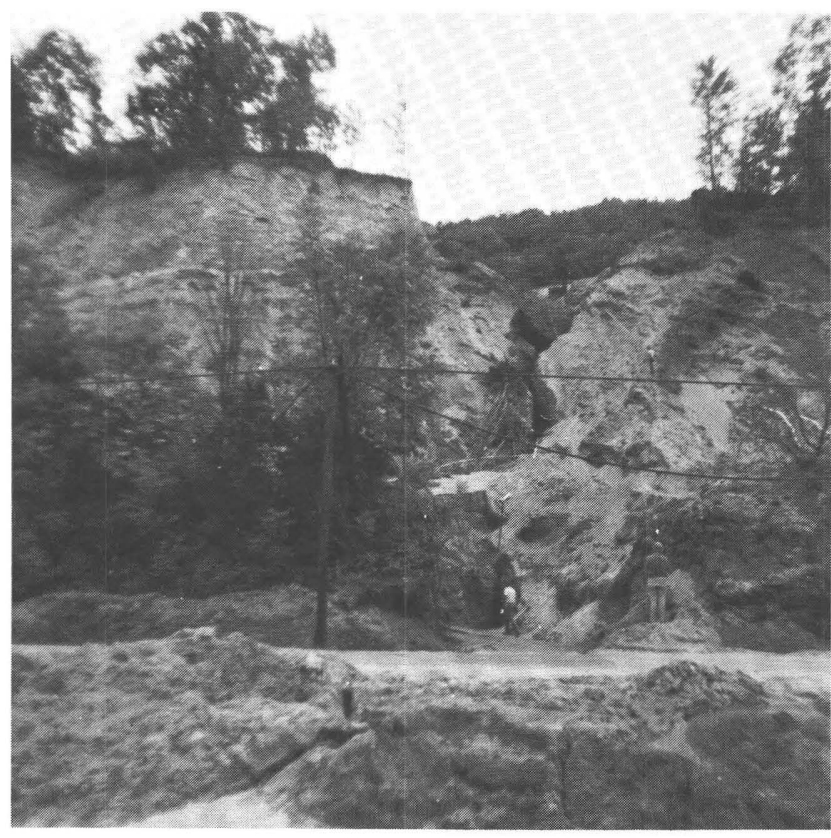

C

Figure 17. Continued.

completely the sand layers and raised the impounded water level to the rim at the face of the terrace.

Representative samples were taken down the face of the rhythmite unit. Torvane and penetrometer tests for shear resistance and compressive strength, respectively, were performed at each sampling station; these stations were 6.54 to $9.79 \mathrm{ft}$ ( $2-3 \mathrm{~m})$ apart vertically. The tests show a low shear resistance for rhythmites in general and the lowest resistance in the upper silty-clays (table 3 ). The clayey-silts have the greatest shear resistance of all the rhythmite units. Shearing resistance in the clays shows an increase as moisture decreases and the clayey-silts show an increase in strength as clay content decreases. The compressive strength of the rhythmite was relatively high-2 to over 5 ton $/ \mathrm{ft}^{2}\left(2-5 \mathrm{~kg} / \mathrm{cm}^{2}\right)$.

Two other field tests were used to determine whether the fine-grained materials were predominantly silt or clay. The first of these tests was based on the portion of the fine-grained soil identification test used for plasticity determinations (American Society for Testing Materials, 1985, D2488). A small sample of the material was rolled between the palms of the hands into a 0.125 -in. $(0.32-\mathrm{cm})$ thread as described in the test procedures (American Society for Testing Materials, 1985) and in Mathewson (1981). If the material could not be rolled, then it was considered to be nonplastic and silt dominated. If the material could be rolled easily to its plastic limit [near the 0.125 -in. $(0.32-\mathrm{cm})$ diameter], then the material was considered to be plastic and clay dominated. We also used the DILATANCY TEST (American Society for Testing Materials, 1985; see also Costa and Baker, 1981). Relative particle size was determined by shaking a small cake of remolded rhythmite material in the hand to see whether water would come to the surface. If the water subsequently disappeared back in the cake, then the specimen was mostly silt; if the sample was mostly clay, then moisture would remain on the surface of the cake. The results of these tests are shown in table 3 in the "Dominant Particle Size" column.

Table 3. Torvane and penetrometer tests of the varved deposits on the Sharon, Vt., slope $[\mathrm{T} / \mathrm{S} / \mathrm{F}$ (ton per square foot) is numerically equivalent to kilograms per square centimeter using these instruments]

\begin{tabular}{|c|c|c|c|}
\hline $\begin{array}{c}\text { Depth } \\
\text { below top } \\
\text { of varve } \\
\text { unit, in meters }\end{array}$ & $\begin{array}{l}\text { Field } \\
\text { torvane } \\
\text { readings, } \\
\text { in } \mathrm{T} / \mathrm{S} / \mathrm{F}\end{array}$ & $\begin{array}{l}\text { Field } \\
\text { penetrometer } \\
\text { readings, } \\
\text { in } \mathrm{T} / \mathrm{S} / \mathrm{F}\end{array}$ & $\begin{array}{l}\text { Dominant } \\
\text { particle } \\
\text { size } \\
\text { (clay/silt) }\end{array}$ \\
\hline \multirow[t]{2}{*}{0.40} & 0.41 & $5.0+$ & Clay. \\
\hline & 0.30 & $5.0+$ & Clayey-silt. \\
\hline \multirow[t]{3}{*}{1.70} & $0.15,0.30$ & $3.4,4.3$ & Clay. \\
\hline & $0.26,0.45$ & -- & Clayey-silt. \\
\hline & --- & $5.0+$ & Sand. \\
\hline \multirow[t]{2}{*}{3.70} & $0.09,0.1$ & 4.0 & Clay. \\
\hline & --- & $5.0+$ & Silty-clay. \\
\hline 5.70 & $0.47,0.49,0.55$ & $3.1,3.3,3.35$ & Clayey-silt. \\
\hline \multirow[t]{2}{*}{8.70} & $0.35,0.43$ & $2.25,2.50,2.75,2.8$ & Clay. \\
\hline & --- & $4.0,4.5$ & Silty-clay. \\
\hline 12.70 & $0.35,0.37,0.39$ & $1.8,2.05,2.15$ & Clay and silty-clay. \\
\hline \multirow[t]{2}{*}{16.40} & $0.46,0.48,0.56$ & $4.3,4.65,5.0^{+}$ & Clayey-silt. - \\
\hline & $0.76,0.07,0.68$ & $4.3,4.65$ & Fine sand. \\
\hline 17.00 & --- & $5.0+$ & $\begin{array}{l}\text { Very fine sand, } \\
\text { some silt } 46-61 \\
\mathrm{~cm} \text { thick. }\end{array}$ \\
\hline
\end{tabular}


The failure took place in two phases. The first phase was a slump-earth flow along the back face of the lower borrow pit. The failure extended from the top of the terrace to the floor of the borrow pit, which is only slightly above the level of Vermont Route 14. The second phase started when the upper pit rim was breached by the firstphase failure. A deep channel was cut down the face of the lower borrow pit by a slurry of sandy material as the upper pit drained. The material from this failure crossed Vermont Route 14, damaging a heavy trunk telephone cable paralleling the eastern side of the road as it passed. This second-phase failure can be classified as a wet sandy earth flow.

\section{SLOPE MOVEMENTS IN ICE-MARGINAL DEPOSITS}

A number of slope failures occurred in ice-marginal deposits at Stoughton Pond (fig. 1; fig. 18) on the North Branch Black River (fig. 1). Stoughton Pond is part of the Army Corps of Engineers North Springfield FloodControl Project. Slope angles measured on the eastern slope of Stoughton Pond averaged $37^{\circ}$ ( 75 percent).

The surface of the glacial terrace on the eastern shore of Stoughton Pond near the dam contains an elongated closed depression (kettle) (fig. 19) that strikes $\mathrm{N}$. $30^{\circ} \mathrm{E}$. The floor of the kettle is about $15 \mathrm{ft}(4.57 \mathrm{~m})$ above the normal pond level. The crest of the western rim of this depression, which is also the eastern rim of the reservoir, is approximately $20 \mathrm{ft}(6.09 \mathrm{~m})$ above the depression floor. The rim width averages about $15 \mathrm{ft}(4.57 \mathrm{~m})$. The rim has been breached several hundred feet (tens of meters) north of the eastern abutment of the dam (fig. 19). The breach extends 5 to $6 \mathrm{ft}(1.52-1.83 \mathrm{~m})$ below the top of the rim.

The terrace materials are crossbedded, fine to coarse, glaciofluvial deposits. Most of these materials contain little silt or clay. The stratigraphic variation from north to south along the eastern shore is indicated in the three descriptions shown in table 4 .

A few elongate lenses [3.0 $\mathrm{ft}(0.91 \mathrm{~m})$ thick] of fine red-brown sand containing gray clayey-silt layers several inches (centimeters) thick can be seen in section on some slide surfaces. The lenses range from approximately $16.0 \mathrm{ft}$ $(4.88 \mathrm{~m})$ across to as much as the entire width of a failure, which may be $100 \mathrm{ft}(30 \mathrm{~m})$ across.

Water flow from the reservoir into the kettle through the breach is indicated by broad aprons of cobbles and gravel on the kettle floor leading from the breach. Saplings growing in the kettle were killed by drowning; in spring 1984, new leaves had sprouted but subsequently wilted. Mud on shrubs and tree trunks in the depression indicated that water stood at least $20 \mathrm{ft}(6.1 \mathrm{~m})$ deep. Also indications of backflow into Stoughton Pond from the kettle as the pond level decreased were found.
Distributary channels, leading from the breach down the slope on the reservoir side of the rim, contained gravels from which the fines had been winnowed. When the pond level dropped below the floor of the breach, a pool of water about $14 \mathrm{ft}(4.28 \mathrm{~m})$ deep remained in the kettle.

The Stoughton Pond slope to the north of the kettle rim showed evidence of long-term creep. Here were found small slope movements of approximately 3 to $26 \mathrm{ft}(0.9-7.9$ $\mathrm{m})$ across; head scarps were 10 to $25 \mathrm{ft}$ (3-7.6 m) upslope from pool level.

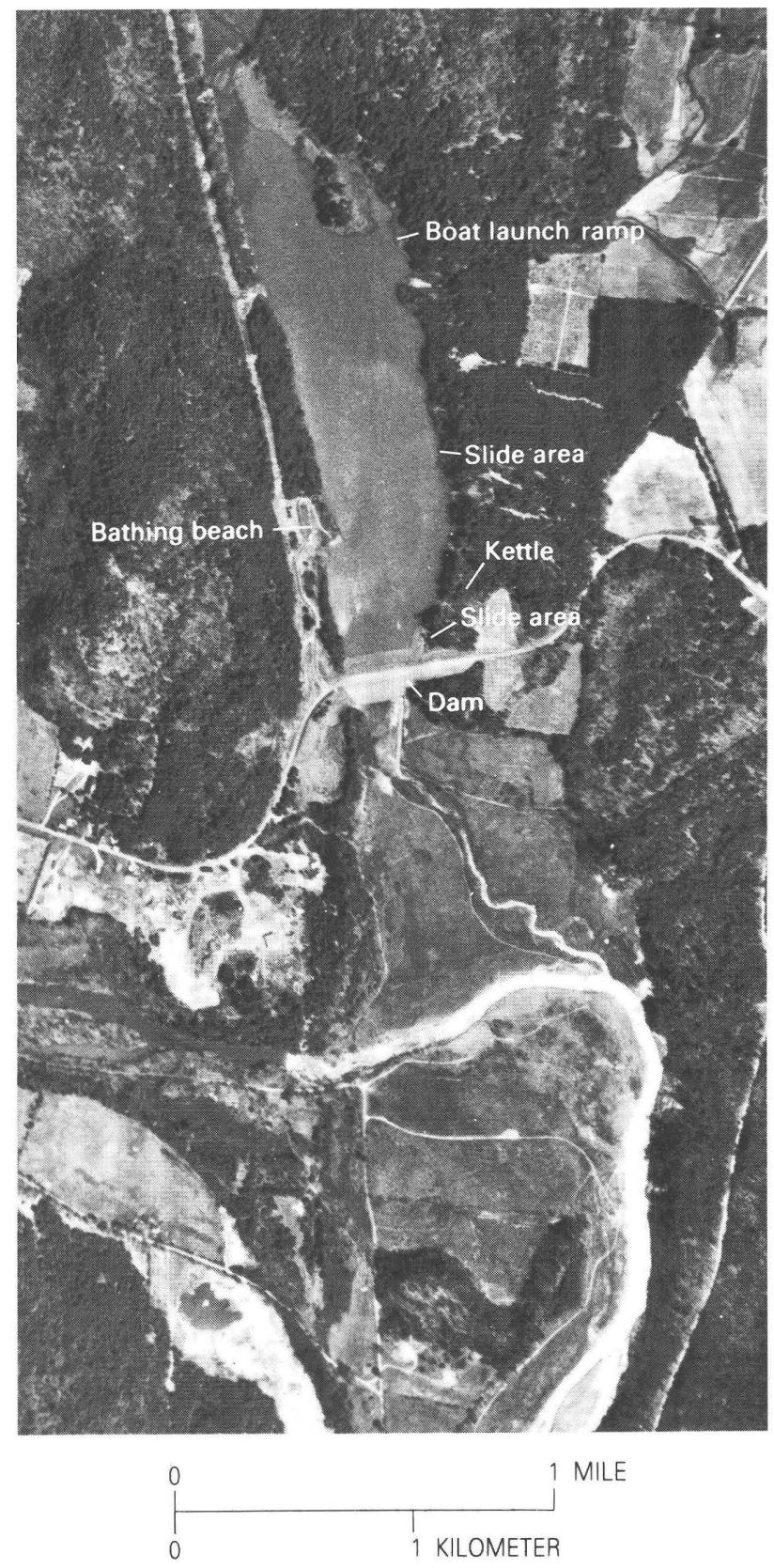

Figure 18. The Stoughton Pond area showing the location of the north and south limits of slide sites on the eastern shore. (Photograph courtesy of AeroGraphics Corp., Bohemia, N.Y.) 


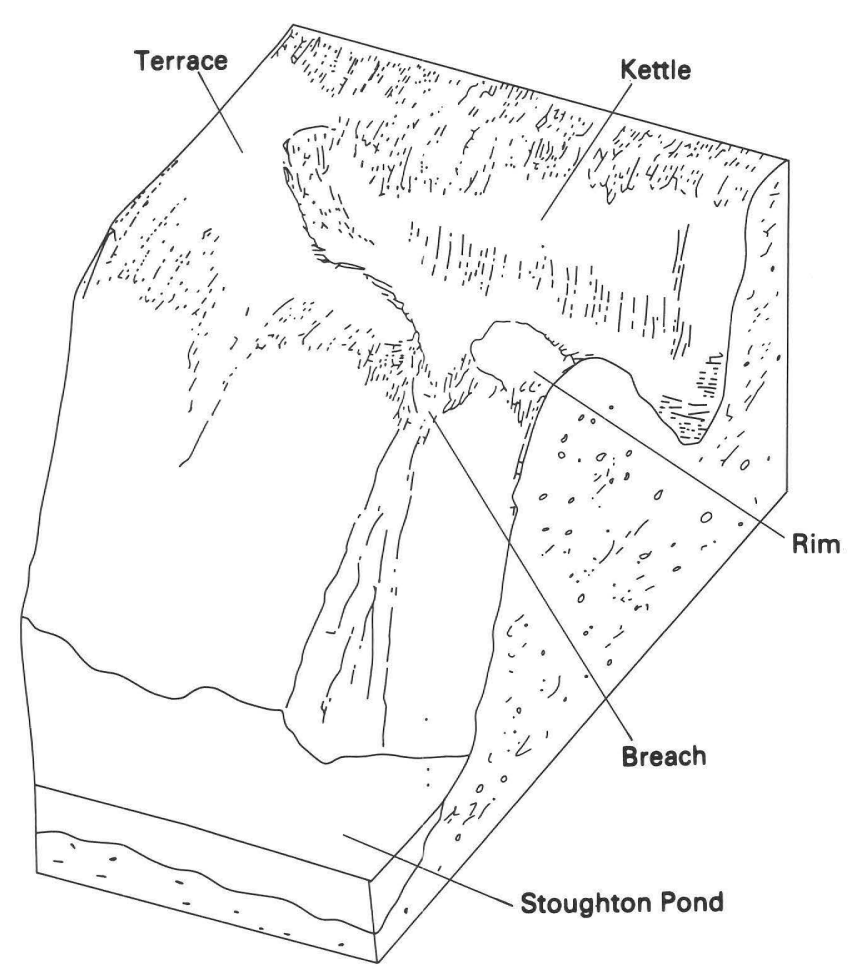

Figure 19. A portion of the eastern shore of Stoughton Pond that shows the reservoir-terrace kettle-rim relation. This sketch is not drawn to scale.

A piping of the glacial deposits also was observed just south of the kettle slides (fig. 20). The pipes varied from a little over 1 to over $3 \mathrm{ft}(0.3$-over $1 \mathrm{~m})$ in diameter. In some of the incipient slide areas, evidence of highvelocity underground flow was seen. Several piping failures beneath the slope surface were evidenced by collapse and (or) sagging of the ground surface over some of these pipes. The soil cover over piping tubes was composed of mats of topsoil and vegetation, underlain by a layer of loam, all of which was held together by a network of plant root systems. Beneath these sagging mats were large cavities (fig. 20A). Sand and gravel on the cavity floors had a flow-produced appearance similar to that seen on some large open slope movements.

Sand and gravel deltas were built up along the eastern shore of the pond near normal pool level, below where these pipes exit the slope (fig. 20B). Below the water level of the pond just off the mouth of these pipe-flow deltas, subaqueous pits were seen. These obviously were excavated by bottom scour of a high-velocity slurry composed of water, sand, and gravel concentrated on the lake bottom at the locations of the pipe exits.

Slope movements at Stoughton Pond were mainly debris flows, approximately 3 to $25 \mathrm{ft}(0.9-7.6 \mathrm{~m})$ wide, and were composed of sands, gravels, boulders, and vegetation. The failures were initiated by the drawdown of the high water in the reservoir created by the May 1984 flooding. Wave erosion along the shoreline at normal pool level had oversteepened the slopes (noted at the time of our study), which aided instability. The red-brown sand lenses have a much lower permeability than the surrounding sands and gravels. Localized high pore-water pressure zones formed in the materials immediately above the lenses and initiated slope movement along lens contacts.

Narrow distributary channels crossing the slide toe area and floored with gravel and cobbles suggested a winnowing out of fines, topsoil, silt, and fine sand by relatively rapid ground-water outflow following reservoir drawdown. The drawdown of the flood-filled reservoir was rapid compared to the drop in the new high groundwater level in the slopes surrounding the pond. The soils were probably already near saturation due to spring snowmelt and rains before reservoir flooding.

As the reservoir was drawn down, the water table remained high due to a lag in the discharge rate from the soil. This situation caused excess pore-water pressure that aided in a decrease in shear resistance of the slope materials (see table 2). The high pore-water pressures also were fed by the water that had ponded in the kettle. The pressure head provided by the water in the kettle and the increased pore pressure in the bank soils allowed subsequent drawdown to weaken the materials on the slope. Failures then were initiated along the southeastern rim of Stoughton Pond.

Other ice-marginal deposits occurred throughout eastern Vermont. These deposits should be considered to have similar failure characteristics as those at Stoughton Pond.

\section{SLOPE MOVEMENTS IN TILL DEPOSITS}

Till deposits were involved in slope failures at two locations within the county. The first location was along Brook Road between Brownsville (fig. 1, localities 2, 9) and Windsor, and the other, along Holbrook Hill Road (fig. 21) between Hartland Four Corners and Brownsville. The latter site is in the vicinity of the Hartland-West Windsor town line.

\section{Brook Road}

Along Brook Road (fig. 13), five slope movements were examined that appear to have been active at various times during the last few years and were reactivated by the 1984 flooding. The materials at these failures were basal or lodgement tills that varied from dark-gray-brown and gray clayey till to dark-brown fine to medium sand and silt and some fine to coarse gravel, cobbles, and boulders that have a trace of some clay; variations were extensive throughout these deposits. An ablation till lacking silt and 
Table 4. Soil stratigraphy of three adjacent areas on the eastern shore of Stoughton Pond

\begin{tabular}{|c|c|c|c|c|c|}
\hline $\begin{array}{l}\text { Depth } \\
\text { from } \\
\text { terrace } \\
\text { surface, } \\
\text { in feet, } \\
()=\mathrm{m}\end{array}$ & $\begin{array}{l}\text { (1) Southern side of boat } \\
\text { ramp approximately } \\
3,937.2 \text { feet }(1,200 \mathrm{~m}) \\
\text { north of site (2) }\end{array}$ & $\begin{array}{l}\text { Depth } \\
\text { from } \\
\text { terrace } \\
\text { surface, } \\
\text { in feet } \\
()=\mathrm{m}\end{array}$ & $\begin{array}{l}\text { (2)Approximately } 200 \\
\mathrm{ft}(61 \mathrm{~m}) \text { north of } \\
\text { eastern abutment }\end{array}$ & $\begin{array}{l}\text { Depth } \\
\text { from } \\
\text { terrace } \\
\text { surface, } \\
\text { in feet } \\
()=\mathrm{m}\end{array}$ & $\begin{array}{c}\text { (3) Approximately } \\
150 \mathrm{ft}(46 \mathrm{~m}) \\
\text { north of eastern abutment }\end{array}$ \\
\hline North & & & & & South \\
\hline $\begin{array}{l}0-0.167 \\
\quad(0-0.051)\end{array}$ & Brown sandy topsoil & $\begin{array}{l}0-0.167 \\
\quad(0-0.051)\end{array}$ & Gray-brown topsoil & $\begin{array}{l}0-0.167 \\
\quad(0-0.051)\end{array}$ & $\begin{array}{l}\text { Gray-brown sandy } \\
\text { topsoil. }\end{array}$ \\
\hline \multirow[t]{13}{*}{$\begin{array}{l}0.167-22.95 \\
\quad(0.051-6.996)\end{array}$} & $\begin{array}{l}\text { Dark-brown fine to } \\
\text { coarse sand, some fine } \\
\text { to coarse gravel, trace } \\
\text { to some cobbles and } \\
\text { boulders, trace of silf. }\end{array}$ & $\begin{array}{l}0.167-.67 \\
\quad(0.051-0.203)\end{array}$ & $\begin{array}{l}\text { Brown silt with a trace } \\
\text { of grit and gravel. }\end{array}$ & $\begin{array}{l}0.167-1.58 \\
(0.051-0.483)\end{array}$ & $\begin{array}{l}\text { Yellowish-brown } \\
\text { fine sand, some } \\
\text { silt, trace of } \\
\text { gravel and clay. }\end{array}$ \\
\hline & & $\begin{array}{l}0.67-1.25 \\
\quad(0.203-0.381)\end{array}$ & $\begin{array}{l}\text { Layer of gravel with a } \\
\text { trace of cobbles. }\end{array}$ & $\begin{array}{l}1.58-3.67 \\
\quad(0.483-1.118)\end{array}$ & $\begin{array}{l}\text { Medium to coarse } \\
\text { sand, some gravel, } \\
\text { trace of silt. }\end{array}$ \\
\hline & & $\begin{array}{l}1.25-22.95 \\
\quad(0.381-6.966)\end{array}$ & $\begin{array}{l}\text { Brown fine to coarse } \\
\text { sand, some fine to } \\
\text { coarse gravel, trace of } \\
\text { silt and boulders. }\end{array}$ & $\begin{array}{l}3.67-3.99 \\
\quad(1.118-1.219)\end{array}$ & $\begin{array}{l}\text { Brown gravel, some } \\
\text { coarse sand, trace } \\
\text { of cobbles. }\end{array}$ \\
\hline & & & & $\begin{array}{l}3.99-4.17 \\
\quad(1.219-1.270)\end{array}$ & $\begin{array}{l}\text { Yellowish-brown, } \\
\text { crossbedded, } \\
\text { fine to medium } \\
\text { sand, some silt, } \\
\text { trace of gravel. }\end{array}$ \\
\hline & & & & $\begin{array}{l}4.17-5.83 \\
\quad(1.270-1.778)\end{array}$ & $\begin{array}{l}\text { Brown cobbly gravel, } \\
\text { some boulders and } \\
\text { coarse sand-damp. }\end{array}$ \\
\hline & & & & $\begin{array}{l}5.83-6.67 \\
\quad(1.778-2.032)\end{array}$ & $\begin{array}{l}\text { Coarse to medium brown } \\
\text { sand, some gravel } \\
\text { trace of silt. }\end{array}$ \\
\hline & & & & $\begin{array}{l}6.67-8.42 \\
\quad(2.032-2.565)\end{array}$ & $\begin{array}{l}\text { Cobbly gravel, some } \\
\text { boulders and coarse } \\
\text { brown sand (cobbles } \\
\text { and boulders are } \\
\text { well rounded). }\end{array}$ \\
\hline & & & & $\begin{array}{l}8.42-9.09 \\
\quad(2.565-2.769)\end{array}$ & $\begin{array}{l}\text { Medium and coarse } \\
\text { light-gray clean } \\
\text { sand, trace of silt } \\
\text { becoming more silty } \\
\text { toward the base. }\end{array}$ \\
\hline & & & & $\begin{array}{l}9.09-9.58 \\
\quad(2.769-2.921)\end{array}$ & $\begin{array}{l}\text { Light-brown to tan } \\
\text { silt and fine sand, } \\
\text { trace of clay. }\end{array}$ \\
\hline & & & & $\begin{array}{l}9.58-9.67 \\
\quad(2.921-2.946)\end{array}$ & Brown clay. \\
\hline & & & & $\begin{array}{l}9.67-10.08 \\
\quad(2.946-3.073)\end{array}$ & $\begin{array}{l}\text { Tan to white fine } \\
\text { sand and silt. }\end{array}$ \\
\hline & & & & $\begin{array}{l}10.08-10.34 \\
\quad(3.073-3.150)\end{array}$ & $\begin{array}{l}\text { Yellow-brown } \\
\text { fine to coarse } \\
\text { sand, some silt-- } \\
\text { damp; white clean } \\
\text { fine sand near } \\
\text { the bottom-dry. }\end{array}$ \\
\hline & & & & $\begin{array}{l}10.34-10.83 \\
\quad(3.150-3.302)\end{array}$ & $\begin{array}{l}\text { Tan silt, some } \\
\text { fine sand, trace } \\
\text { of clay, light- } \\
\text { gray gravelly } \\
\text { medium sand-dry; } \\
\text { light-gray medium } \\
\text { to coarse sand-dry. }\end{array}$ \\
\hline
\end{tabular}




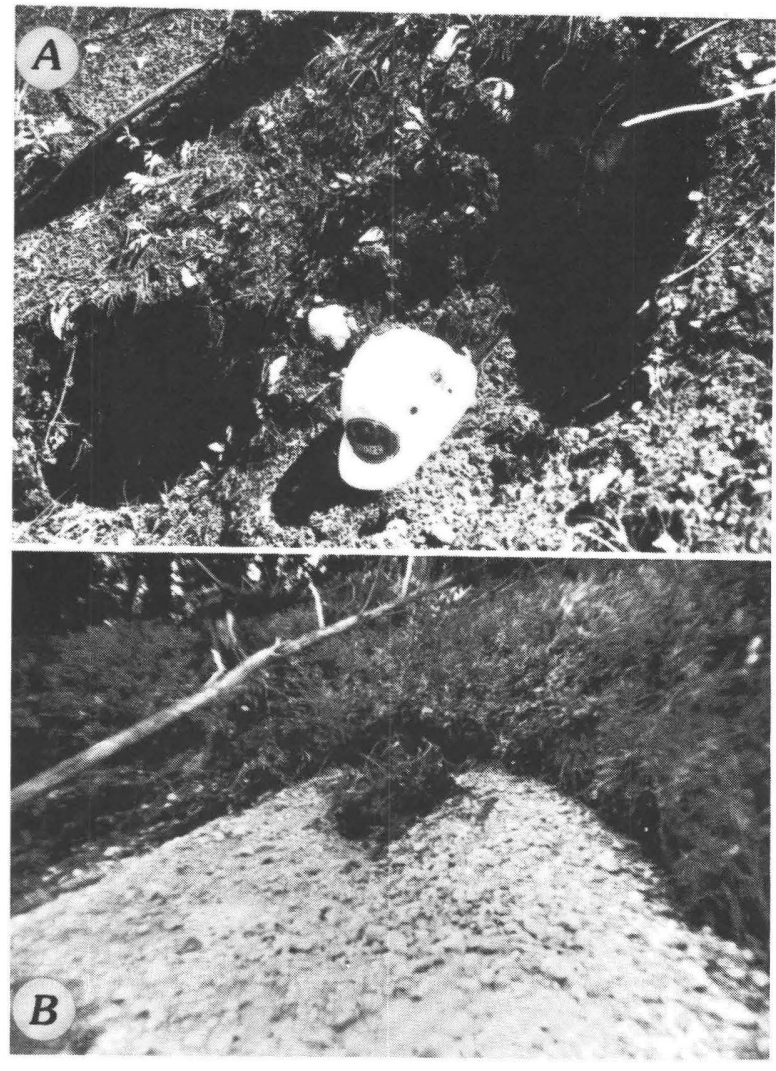

Figure 20. Piping failures in the eastern slope of Stoughton Pond; an impoundment. A, Collapse pits over pipes. B, Outflow delta deposits from mouth of pipe at pond level.

clay overlaid the lodgement till. The natural slope angles along Brook Road averaged $32^{\circ}$ to $40^{\circ}$ (62-84 percent).

About $0.5 \mathrm{mi}(0.8 \mathrm{~km})$ east of Brownsville along Brook Road was a small slump. The failure was $100 \mathrm{ft}$ $(30.5 \mathrm{~m})$ wide and extended vertically upslope from the road for $55 \mathrm{ft}(16.8 \mathrm{~m})$. The scarp was about $9 \mathrm{ft}(2.7 \mathrm{~m})$ high and had an angle of $76^{\circ}$ (about 164 percent). The material in the scarp was dry to moist ablation till. Seeps and springs were common in the toe area of the failure and appeared to be emerging along the contact between the upper ablation and a lower basal till unit.

A large landslide occurred about $0.4 \mathrm{mi}(0.6 \mathrm{~km})$ west of the eastern end of Brook Road. The failure was a series of shallow block slides. The slope angle was $43^{\circ}(93$ percent), and the failure measured $200 \mathrm{ft}(60.9 \mathrm{~m})$ wide by about $50 \mathrm{ft}(15.2 \mathrm{~m})$ upslope. The material was a graybrown sand and silt and had some gravel- to boulder-sized fragments and traces of clay. At the level of the road, the material had piled up and rotated slightly. Highway crews had been removing the toe material, which had flowed out onto the road.

The other slope movements along Brook Road were in the same till sequence but were not as thick and rested on steeply dipping bedrock surfaces. These tills apparently absorbed large amounts of water as a result of the aboveaverage precipitation (table 1) during the period beginning in fall 1983 and ending in spring 1984. Additional heavy rains in late spring (May 27 through 31 in particular) precipitated sliding by saturating the soil, thus reducing frictional forces.

\section{Holbrook Hill Road}

The materials involved in the Holbrook Hill Road slides (fig. 21) were very compact lodgement tills overlain by relatively loose and permeable ablation till with a variable thickness of approximately 60 to over $100 \mathrm{ft}$ (18-over $30.5 \mathrm{~m})$. Numerous landslides have occurred previously in this valley, as indicated by hummocky profiles on the slopes. We noted that several slides in this hummocky terrain were reactivated in spring 1984; one

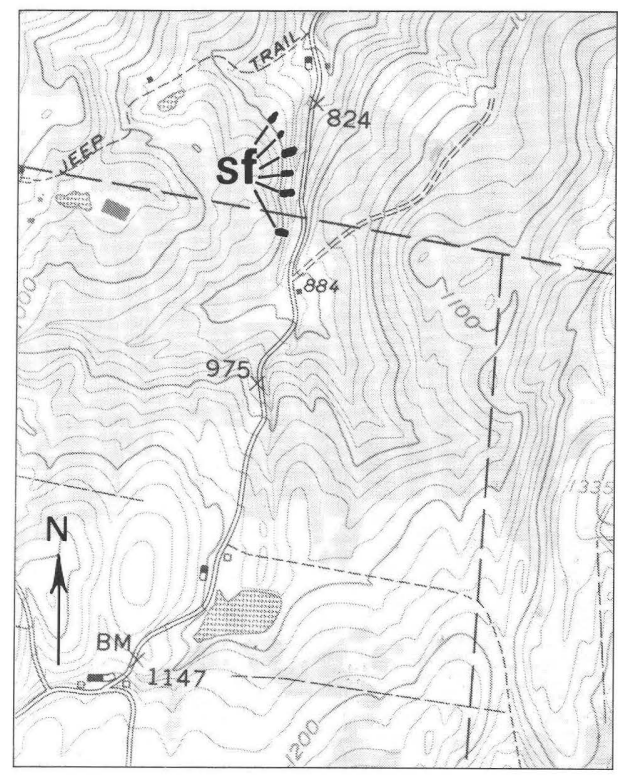

Base from U.S. Geological Survey 1:24 000 Hartland, 1959

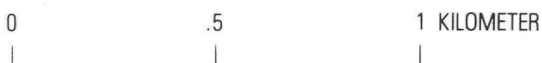

CONTOUR INTERVAL 20 FEET

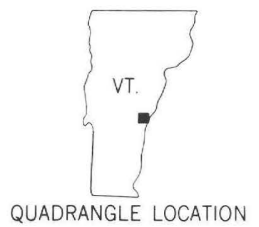

Figure 21. The Holbrook Hill Road slide area. The letters "sf" point out the slope failures. 
slide took out a telephone pole. The head scarp of this latter slide is at the edge of an old abandoned road that is part of a larger interconnected network of abandoned roads upslope of the failure. The road appears to have channeled water from higher elevations into the permeable ablation till. The ablation till extended for at least $100 \mathrm{ft}$ $(30.5 \mathrm{~m})$ upslope from the slide and was composed of a dark-brown fine to coarse sand that has 5 (trace) to 30 (some) percent silt and fine to coarse gravel and cobbles. These soils, which had a more open texture, were damp at the time of sampling. The lodgement till underlying the ablation till was composed of sticky gray clay that had a trace to some fine to medium sand and gravel and some cobbles and small boulders.

Within a distance of $0.2 \mathrm{mi}(0.322 \mathrm{~km})$, six active slides were observed; the largest of these was $60 \mathrm{ft}(18.3 \mathrm{~m})$ wide and $105 \mathrm{ft}(32 \mathrm{~m})$ upslope. Many trees up to $1 \mathrm{ft}(0.305$ $\mathrm{m})$ in diameter at breast height were taken down by the failure. After the failure, water seeped out of the head scarp along the contact between the ablation and lodgement tills, and the slide plane was a wet slick mud.

Although a small stream is located at the toe of the slope, it apparently had not cut the toe and, thus, was not the cause of failure. This appeared to be the case for other slope movements in similar basal till deposits in the towns of Hartland and West Windsor. The streams in this area appeared to erode till with difficulty, whereas slower moving ground water soaked these soils a few inches (millimeters) at a time. The loose open-textured ablation till had a high hydraulic conductivity. Ground-water flow through the ablation till eventually soaked into the lodgement till for a short distance beneath the contact, producing a thin layer of soupy, sticky mud. This layer formed the zone of failure and allowed the overlying materials to move downslope. The actual slope movement was a combination of earth flow and block slide.

\section{SUMMARY AND CONCLUSIONS}

Slope movements studied in Windsor County, Vt., indicated that susceptibility to slope instability is high in practically every soil type in the area, especially when large volumes of water are added rapidly. The greater-thannormal precipitation in Windsor County for November 1983 through April 1984 (table 1) saturated slope soils. The absence of significant drying during the period and abnormal rainfall between May 29 and 31, 1984, exacerbated the problem (table 1; National Oceanic and Atmospheric Administration, 1984e). The occurrence of multiple failures during and immediately following the intense rainstorms of May 1984 (J. E. Dyer and Thomas Coen, Project Managers, North Hartland and North Springfield Flood-Control Dams, respectively, U.S. Army
Corps of Engineers, personal commun., 1984; C. A. Ratté, Vermont State Geologist, personal commun., 1984) indicates that the landslides were triggered by a buildup of pore pressure resulting from very high water tables.

Lake-bottom sediments, or rhythmites, were found to present the greatest landslide problem in the study area. Earth flows were the landslide type most commonly associated with these deposits. The earth flows occurred as rafts of intact material riding on layers of fluidized material. Some failures had either rotational or slump movement in the scarp area; others had either translational or block slide movement. The surface layer of slide material at the North Springfield Flood-Control Reservoir had buckled in the toe area. In some instances, the velocity of the slide mass and fluidity of the material developed overthrust sheets that would ramp up onto the sheets ahead that had slowed or stopped in their advance downslope. At the leading edge of these thrust sheets, a trough paralled to this edge contained the fluidized finegrained substrate.

Ground-water flow in the reservoir slopes had a major effect on movement in these slopes. Water flow in the rhythmite deposits in these slopes was found to be confined to the silt and sand layers; instances of piping were associated with some of the earth flows. At both reservoirs, filling due to heavy rain and snowmelt runoff raised the water table. As the reservoirs were drawn down, the higher ground-water level flowed toward them, which exited the slope above pool level for some time. Where thick, noncohesive sand layers were exposed by slope failures along the rims of the reservoirs, sand was removed as the water flowed out and formed pipes.

At several locations, pipestem structure on trees was observed. Pipestem structure can be a phototropic response by the trees or caused by hillslope creep. The number of trees involved at the sites investigated indicates the latter to be the case. This is supported by tree-ring data from the Vermont Route 11 landslide.

The slope failure at Sharon appears to have occurred in two phases. The first, a slump earth flow, took place along the back face of the lower borrow pit, which separated it from the coarse deposits in the lower pit and allowed the upper pit to fill with water. The second-phase failure began when the upper pit rim was breached by the first-phase failure, which released water contained in that pit. A deep channel, which cut down the face of the lower pit, resulted from the second failure as a slurry of sandy material ran down when the upper pit drained.

Slope movements in the ice-marginal deposits were mainly debris flows initiated by the drawdown of the high waters in reservoirs after the May 1984 flooding. These failures were accompanied by piping in places. At the Stoughton Pond site, a high-pressure head was maintained by water ponded in the terrace kettle on the eastern rim of the Stoughton Pond Reservoir; this probably aided the 
piping. Drawdown of the reservoirs was rapid as compared to the rate the water-table level declined in the surrounding slopes, thus creating excess pore-water pressure that triggered slope failures.

Slope movements in till deposits at the Brook Road site resulted from reduced frictional forces brought on by saturation after the prolonged and intense precipitation infiltrating these sediments that were on bedrock slopes. At the Holbrook Hill Road site, the till deposits were a combination of an ablation till overlying a clayey lodgement till. Water traveling through the open network, highconductivity ablation till saturated the surface of the clayey lodgement till below, thus creating a layer of soupy, sticky mud that became the slide surface.

Some of the significance in these studies is in the similarity of failed material types over a great distance relative to grain size and engineering characteristics. The shear strengths in the various types of deposits tested ranged from a low of 0.032 to over $0.5 \mathrm{ton} / \mathrm{ft}^{2}(0.032-0.5$ $\left.\mathrm{kg} / \mathrm{cm}^{2}\right)$, the average shear resistance was $0.208 \mathrm{ton} / \mathrm{ft}^{2}$ $\left(0.208 \mathrm{~kg} / \mathrm{cm}^{2}\right)$. The finer sediments also had the greatest cohesiveness, whereas the sandier layers had the least. Because the sandier layers have a higher hydraulic conductivity than the finer sediments, they behave as aquifers. After slope failure occurred, it was common to find water seeping from the sandier layers. If the sandy layer was thick enough and became exposed during slope failure, then it was subject to piping by escaping ground water.

Compressive strengths are related to moisture content and grain size of the materials; whether the field tests were taken normal or parallel to the bedding seemed to have no affect on the results. Overall, the silty-sands, silty-clays, and clayey-silts had the highest compressive strength, which averaged $3.16 \mathrm{ton} / \mathrm{ft}^{2}\left(3.16 \mathrm{~kg} / \mathrm{cm}^{2}\right)$.

\section{REFERENCES CITED}

American Society for Testing Materials, 1985, Annual book of ASTM standards, Sect. 4 Construction, soil and rockBuilding stones: Philadelphia, Pa., American Society for Testing Materials, 970 p.

Campbell, R. H., 1975, Soil slips, debris flows, and rainstorms in the Santa Monica mountains and vicinity, southern California: U.S. Geological Survey Professional Paper $851,51 \mathrm{p}$.

Costa, J. E., and Baker, V. R., 1981, Surficial geology-Building with the earth: New York, John Wiley \& Sons, Inc., 498 p.

Faul, Henry, Stern, T. W., Thomas, H. H., and Elmore, P. L. D., 1963, Ages of intrusion and metamorphism in the northern Appalachians: American Journal of Science, v. 261, p. 1-19.

Hepburn, J. C., Trask, N. J., Rosenfeld, J. L., Thompson, J. B. Jr., 1984, Bedrock geology of the Brattleboro quadrangle. Vermont-New Hampshire: Vermont Geological Survey,
Agency of Environmental Conservation, Bulletin No. 32, $162 \mathrm{p}$.

Mathewson, C. C., 1981, Engineering geology: Columbus, Ohio, Charles E. Merrill Publishing Co., 450 p.

National Oceanic and Atmospheric Administration, 1983a, Climatological data New England, September: National Oceanic and Atmospheric Administration, v. 95, no. 9.

1983b, Climatological data New England, October:

National Oceanic and Atmospheric Adminstration, v. 95 , no. 10.

1983c, Climatological data New England, November: National Oceanic and Atmospheric Administration, v. 95, no. 11 .

_ 1983d, Climatological data New England, December: National Oceanic and Atmospheric Administration, v. 95, no. 12.

- 1984a, Climatological data New England, January: National Oceanic and Atmospheric Administration, v. 96, no. 1.

1984b, Climatological data New England, February: National Oceanic and Atmospheric Administration, v. 96, no. 2 .

— 1984c, Climatological data New England, March: National Oceanic and Atmospheric Administration, v. 96, no. 3 .

1984d, Climatological data New England, April: National Oceanic and Atmospheric Administration, v. 96, no. 4 .

1984e, Climatological data New England, May: National Oceanic and Atmospheric Administration, v. 96, no. 5. 1984f, Climatological data New England, June: National Oceanic and Atmospheric Administration, v. 96, no. 6.

Phipps, R. L., 1974, The soil creep-curved tree fallacy: Journal of Research, U.S. Geological Survey, v. 2, no. 3, p. 371-377.

Schuster, R. L., 1980, Landslides related to reservoirs: Geological Society of America, Abstracts with Program, v. 12, p. 303.

Sharpe, C. F. S., 1938, Landslides and related phenomena: New York, Columbia University Press, $137 \mathrm{p}$.

Skempton, A. W., and DeLory, F. A., 1957, Stability of natural slopes in London Clay, in International Conference, Soil Mechanics Foundation Engineering, 4th, London, 1957, Proceedings, v. 2, p. 378-381.

Stewart, D. P., and Mac Clintock, Paul, 1969, The surficial geology and Pleistocene history of Vermont: Vermont Geological Survey, Department of Water Resources, Bulletin No. 31, 251 p.

Terzaghi, Karl, 1950, Mechanism of landslides, in Application of geology to engineering practice (Berkey volume): Geological Society of America, p. 83-123.

Terzaghi, Karl, and Peck, R. B., 1948, Soil mechanics in engineering practice: New York, John Wiley \& Sons, 566 p.

Varnes, D. J., 1978, Slope movement types and processes, in Schuster, R. L., and Krizek, R. J., editors, Landslides analysis and control: Transportation Research Board, Special Report 176, p. 11-33.

Weller, J. M., 1960, Stratigraphic principles and practice: New York, Harper \& Brothers, Publisher, 725p.

Zaruba, Quido, and Mencl, Vojtech, 1982, Landslides and their control: New York, Elsevier, and Prague, Academia, 324 p. 




\section{SELECTED SERIES OF U.S. GEOLOGICAL SURVEY PUBLICATIONS}

\section{Perlodicals}

Earthquakes \& Volcanoes (issued bimonthly).

Preliminary Determination of Epicenters (issued monthly).

\section{Technical Books and Reports}

Professional Papers are mainly comprehensive scientific reports of wide and lasting interest and importance to professional scientists and engineers. Included are reports on the results of resource studies and of topographic, hydrologic, and geologic investigations. They also include collections of related papers addressing different aspects of a single scientific topic.

Bulletins contain significant data and interpretations that are of lasting scientific interest but are generally more limited in scope or geographic coverage than Professional Papers. They include the results of resource studies and of geologic and topographic investigations; as well as collections of short papers related to a specific topic.

Water-Supply Papers are comprehensive reports that present significant interpretive results of hydrologic investigations of wide interest to professional geologists, hydrologists, and engineers. The series covers investigations in all phases of hydrology, including hydrogeology, availability of water, quality of water, and use of water.

Circulars present administrative information or important scientific information of wide popular interest in a format designed for distribution at no cost to the public. Information is usually of short-term interest.

Water-Resources Investigations Reports are papers of an interpretive nature made available to the public outside the formal USGS publications series. Copies are reprocuuced on request unlike formal USGS publications, and they are also available for public inspection at depositories indicated in USGS catalogs.

Open-File Reports include unpublished manuscript reports, maps, and other material that are made available for public consultation at depositories. They are a nonpermanent form of publication that may be cited in other publications as sources of information.

\section{Maps}

Geologic Quadrangle Maps are multicolor geologic maps on topographic bases in $71 / 2$-or 15-minute quadrangle formats (scales mainly $1: 24,000$ or $1: 62,500$ ) showing bedrock, surficial, or engineering geology. Maps generally include brief texts; some maps include structure and columnar sections only.

Geophysical Investigations Maps are on topographic or planimetric bases at various scales; they show results of surveys using geophysical techniques, such as gravity, magnetic, seismic, or radioactivity, which reflect subsurface structures that are of economic or geologic significance. Many maps include correlations with the geology.

Miscellaneous Investigations Series Maps are on planimetric or topographic bases of regular and irregular areas at various scales; they present a wide variety of format and subject matter. The series also includes 7 1/2-minute quadrangle photogeologic maps on planimetric bases which show geology as interpreted from aerial photographs. Series also includes maps of Mars and the Moon.
Coal Investigations Maps are geologic maps on topographic or planimetric bases at various scales showing bedrock or surficial geology, stratigraphy, and structural relations in certain coal-resource areas.

Oil and Gas Investigations Charts show stratigraphic information for certain oil and gas fields and other areas having petroleum potential.

Miscellaneous Field Studies Maps are multicolor or black-andwhite maps on topographic or planimetric bases on quadrangle or irregular areas at various scales. Pre-1971 maps show bedrock geology in relation to specific mining or mineral-deposit problems; post-1971 maps are primarily black-and-white maps on various subjects such as environmental studies or wildemess mineral investigations.

Hydrologic Investigations A tlases are multicolored or black-andwhite maps on topographic or planimetric bases presenting a wide range of geohydrologic data of both regular and irregular areas; principal scale is 1:24,000 and regional studies are at 1:250,000 scale or smaller.

\section{Catalogs}

Permanent catalogs, as well as some others, giving comprehensive listings of U.S. Geological Survey publications are available under the conditions indicated below from the U.S. Geological Survey, Books and Open-File Reports Section, Federal Center, Box 25425, Denver, CO 80225. (See latest Price and Availability List.)

"Publications of the Geological Survey, 1879-1961" may be purchased by mail and over the counter in paperback book form and as a set of microfiche.

"Publications of the Geological Survey, 1962-1970" may be purchased by mail and over the counter in paperback book form and as a set of microfiche.

"Publications of the U.S. Geological Survey, 1971-1981" may be purchased by mail and over the counter in paperback book form (two volumes, publications listing and index) and as a set of microfiche.

Supplements for 1982, 1983, 1984, 1985, 1986, and for subsequent years since the last permanent catalog may be purchased by mail and over the counter in paperback book form.

State catalogs, "List of U.S. Geological Survey Geologic and Water-Supply Reports and Maps For (State)," may be purchased by mail and over the counter in paperback booklet form only.

"Price and Availabillty List of U.S. Geological Survey Publications," issued annually, is available free of charge in paperback booklet form only.

Selected copies of a monthly catalog "New Publications of the U.S. Geological Survey" available free of charge by mail or may be obtained over the counter in paperback booklet form only. Those wishing a free subscription to the monthly catalog "New Publications of the U.S. Geological Survey" should write to the U.S. Geological Survey, 582 National Center, Reston, VA 22092.

Note.--Prices of Government publications listed in older catalogs, announcements, and publications may be incorrect. Therefore, the prices charged may differ from the prices in catalogs, announcements, and publications. 


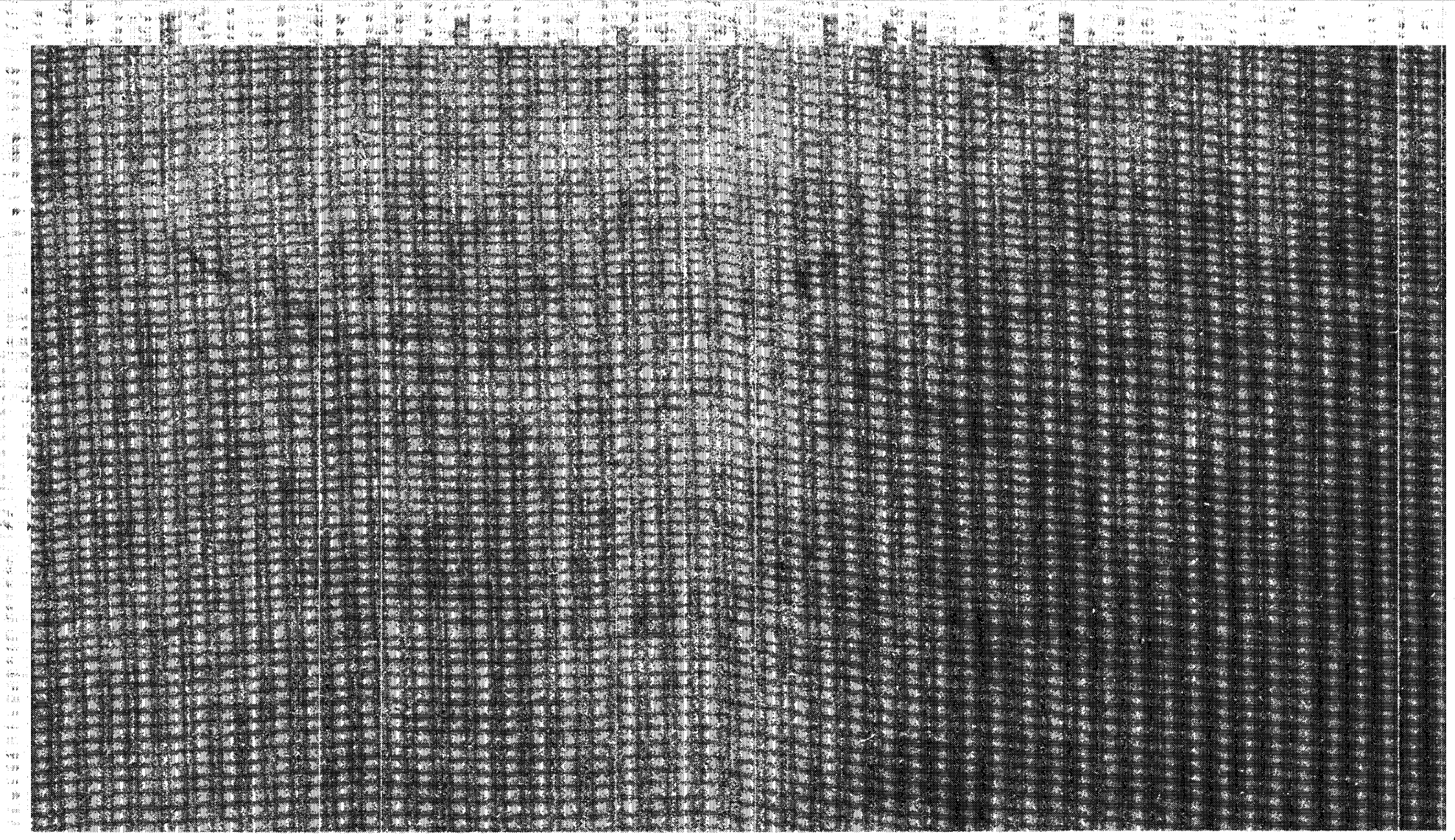

